\title{
Reading Abdallāh b. Abdallāh al-Tarjumān's Tuhfa (1420) in the Ottoman Empire: Muslim-Christian Polemics and Intertextuality in the Age of "Confessionalization""
}

\author{
Leyendo la Tuhfa de Abdallāh b. Abdallāh al-Tarŷumān \\ (1420) en el Imperio Otomano: \\ Polémica Cristiano-Musulmana e Intertextualidad \\ en la época de la "Confesionalización"
}

\author{
Tijana Krstić \\ Central European University, Budapest
}

\begin{abstract}
In 1604, a charismatic Sufi sheikh from Tunis commissioned the translation into Ottoman Turkish of Abdallāh b. Abdallāh al-Tarjumān's polemical text entitled Tuhfat al-Adīb fì alradd 'alā ahl al-ṣalīb (1420), with the intention of presenting it to Ottoman Sultan Ahmed I. Soon after, this text became one of the most widely known and disseminated anti-Christian polemical texts in the Islamic world, and by the late ninteenth century, in Europe as well. The article examines the circumstances of Tuhfa's translation from Arabic into Ottoman
\end{abstract}

En 1604, un carismático sufí de Túnez encargó la traducción al turco otomano del texto de polémica titulado Tuhfat al-Adīb fì al-radd 'alā ahl al-șal̄o (1420) de Abdallāh b. Abdallāh al-Tarjumān, con la intención de presentárselo al Sultán otomano Ahmed I. Poco después, este texto se convirtió en uno de los textos de polémica anti-Cristiana mejor conocidos y leídos en el mundo islámico y en Europa, a finales del siglo XIX. Este artículo estudia las circunstancias en que se realizó la traducción de la Tuḥfa del árabe al turco

\footnotetext{
* I would like to thank John Curry, Sara Nur Y1ldız, Gottfried Hagen, and especially Ferenc Csirkés for their helpful comments and suggestions while researching and writing this article. I am also indebted to Rashed Daher and Aziz al-Azmeh for their help with sources in Arabic, István Ormos for his help with sources in Arabic and Greek, and Ferenc Csirkés for his help with sources in Persian. Thanks to Robert Dankoff's generous help with transliteration and translation, I dared to append a critical edition and translation of a text in Ottoman Turkish. Whatever mistakes remain, they are mine only. Research for this essay was made possible by the American Council of Learned Societies/National Endowment for Humanities Fellowship (2009-10); American Research Institute in Turkey/ National Endowment for Humanities Fellowship (2009-10), and Central European University's Individual Research Scheme grant (Summer 2011).
} 
Turkish, the actors involved, the narrative's trajectory from Tunis to Istanbul, its reception by the Ottoman reading public, as well as impact on the development of an Ottoman polemical genre of self-narrative of conversion to Islam. Transcription and translation of such an Ottoman narrative, which appears to have been directly influenced by Tuhfa, is featured in the article's appendix. By focusing on the trajectory of a single text belonging to the genre of religious polemics, the article bridges the traditionally disconnected academic discussions pertaining to the early modern Iberian, North African and Ottoman history and demonstrates their inherent connectivity in the age of confessional polarization $\left(16^{\text {th }}-17^{\text {th }}\right.$ centuries).

Key words: Polemics; conversion; narrative; intertextuality; Ottoman Empire; Tunis; Translation. otomano, los actores involucrados en esa traducción, la narrativa de su trayectoria desde Túnez hasta Estambul, su recepción por el público letrado otomano $\mathrm{y}$, finalmente, su impacto en el desarrollo del género de polémica otomana en las narrativas de conversión al Islam. En el apéndice de este artículo se incluye una transcripción y traducción de esa narrativa, que parece estar directamente influida por la Tuhfa. Mediante el estudio de la trayectoria de un único texto perteneciente al género de la polémica religiosa, este artículo evita las discusiones académicas, tradicionalmente desconectadas entre sí porque estudian la historia moderna ibérica, norte africana y otomana de forma separada, demostrando así su íntima conexión en la época de polarización confesional (ss. XVI y XVII).

Palabras clave: Polémica; conversión; narrativa; intertextualidad; Imperio Otomano; Túnez; traducción.

\section{Introduction}

In 1420 a convert to Islam named Abdallāh b. Abdallāh al-Tarjumān completed the polemical text in Arabic entitled Tuhfat al-Adīb fì alradd 'alā ahl al-șalīb (Gift of the Lettered One for the Refutation of the People of the Cross). ${ }^{1}$ In the first part of this account, he tells the story of how he, a native of Mallorca, who was educated in theology in Lleida and in Bologna to become a Franciscan priest, discovered the truth of Islam in the Gospel of John and travelled to Tunis where he converted in the presence of the Hafsid sultan Abū al-'Abbās Aḥmad around 1387. In the second part of the Tuhfa, al-Tarjumān speaks about his career as the customs official and interpreter in the service of the sultan, as well as about the biography of his patron and political situation in Tunis at the time. Finally, in the third and longest part that consists of nine chapters, Abdallāh al-Tarjumān turns to the polemic

\footnotetext{
${ }^{1}$ Names and titles in Arabic are transcribed according to the system of the International Journal of Middle Eastern Studies. Names in Ottoman Turkish are given according to modern Turkish orthography. This orthography is modified to indicate long vowels, as well as letters 'ayn (') and hamze (') when transcribing special Ottoman terms and quotations from the text given in the appendix.
} 
against Christianity based mostly on the quotations from the scriptures, with some references to the Qur'ān, hadìth and works of the wellknown Muslim polemicists against Christianity, such as al-Jāhịiz, alHashīmī, al-Ṭabarī, al-Ghazālī, Ibn Hazm, and Ibn Taymiyyah. The overall polemical argument of the Tuhfa is in line with the traditional Muslim polemical concept of tahrîf, which maintains that the Christian (and Jewish) scriptures originally faithfully transmitted the word of God and teachings of the prophets but were corrupted over time, which led to Christianity's supersession by Islam. ${ }^{2}$

Only towards the end of the nineteenth century was it established that Abdallāh al-Tarjumān was in fact the Muslim name of Fra Anselm Turmeda, an author well known in the late medieval Catalan-speaking world for several of his other works in Catalan, which he apparently wrote after his conversion to Islam but without referring to his Muslim identity. ${ }^{3}$ This authorial bifurcation has been inciting a lively debate among scholars for more than a century now. ${ }^{4}$ However, although this paper will be concerned with the issues of authorship, it will not focus on Anselm Turmeda/Abdallāh al-Tarjumān but on the history of the Tuhfa's reception by and impact on the Muslim literary audience in the Ottoman Empire. It will ask the question of how this account, which seems to have gone unnoticed by Muslim literati for almost two centuries after being written, reached the status of one of the most popular and readily recognizable anti-Christian polemical texts both in the Middle East and in Europe, seeing many printings and translations into various languages already in the nineteenth century and maintaining its appeal to this day. ${ }^{5}$ Building on the work of the Spanish Arabist Míkel

${ }^{2}$ On the argument of the Tuhfa see Epalza, Fray Anselm Turmeda ('Abdallāh alTaryumān) y su polémica islamocristiana, pp. 85-91.

${ }^{3}$ His other works include Llibre de bons amonestaments [Book of good admonishments] (ca. 1396-98), Cobles de la divisió del regne de Mallorques [Popular songs of the division of the Majorcan Kingdom] (1398), four short, rhymed Profecies (ca. 1405 and after), and Disputa de l'ase [Dispute of the mule] (ca. 1417-18).

${ }^{4}$ For recent discussions on this issue and overview of the scholarly debates see Álvarez, "Anselm Turmeda: The Visionary Humanism of a Muslim Convert and Catalan Prophet", pp. 172-9; Szpiech, "The Original is Unfaithful to the Translation: Conversion and Authenticity in Abner of Burgos and Anselm Turmeda"; and Szpiech, Conversion and Narrative. Reading and Religious Authority in Medieval Polemic, pp. 200-213.

${ }^{5}$ A French translation by J. Spiro appeared in 1886. It was preceded by two translations into Ottoman Turkish published in 1874 and 1876, which are discussed later in the article. A Spanish translation was undertaken by Epalza in 1971, in the first edition of his Fray 
de Epalza and his landmark study of the Tuhfa, I will argue that the key to understanding this development is the account's translation into Ottoman Turkish in 1604 which, however, had consequences beyond those that Epalza could discern without being acquainted with the Ottoman literary and religio-political scene of the seventeenth century.

The ensuing discussion will first focus on the circumstances of the Tuhfa's arrival in the Ottoman Empire, the historical context in which it transpired, and the people who were instrumental in this textual transfer, as a window into the social and textual networks as well as religiopolitical developments that spanned the Mediterranean at the turn of the seventeenth century. In particular, I am interested in bridging the traditionally disconnected academic discussions pertaining to the early modern Iberian, North African and Ottoman history by focusing on a single text whose intriguing trajectory cannot be understood without the insights from all three fields and realization of their inherent connectivity. In the second part of the article, the discussion will take up the issue of the Tuhfa's impact on the Ottoman literary public by examining in detail an unknown Ottoman text from the early seventeenth century that bears a striking resemblance to it. The critical edition and translation into English of this text, ostensibly authored by a former Orthodox Christian priest from Athens c. 1625, is given in the appendix to the article. As it will be argued, a close reading of this text helps to chart out the Tuhfa's trajectory from Tunis to Istanbul, raising issues about the appeal of polemical texts of autobiographical nature across confessional boundaries in the age of intense religious debates that gripped both Christian and Muslim communities around the Mediterranean (and beyond) between the sixteenth and eighteenth centuries. Finally, the last part of the paper will be dedicated to the discussion of various Ottoman narratives whose manuscript traditions intersect with that of the Tuhfa. I will suggest that, starting in the early seventeenth century, the Tuhfa likely became the blueprint for the Ottoman polemical self-narratives of conversion. This section will also address the issues of genre and authorship in a broader early modern comparative

Anselm Turmeda. Recently, three translations into English of the introductory, self-narrative part of the Tuhfa were published. See Boase, "Autobiography of a Muslim Convert: Anselm Turmeda (c. 1353-c. 1430)"; García-Arenal, "Dreams and Reason: Autobiographies of Converts in Religious Polemics" and Reynolds, Interpreting the Self: Autobiography in the Arabic Literary Tradition, pp. 194-201. 
perspective to examine the reasons behind the Tuhfa's successful transplantation to the Ottoman milieu and its eventual fame as one of the most recognizable Muslim polemics against Christianity.

\section{Part I. Abdallāh b. Abdallāh al-Tarjumān's Tuḥfa travels to the Ottoman Empire}

On zi l-hicce 20, 1012/May 9, 1604, only a few months after Ottoman Sultan Ahmed I (1603-1617) acceded to the throne in Istanbul, a charismatic sheikh (Sufi elder) from Tunis by the name of Abu 1Ghayth b. Muhammad al-Qashshāsh (d. 1621) dedicated to the young sovereign a copy of Abdallāh al-Tarjumān's work whose translation into Ottoman Turkish he commissioned from a certain Muhammad b. Sha 'ban (Tr. Mehmed b. Şa 'ban). ${ }^{6}$ In his dedication, the sheikh praises the sultan, whom he addresses as the "shadow of God on earth" and the "caliph of all Muslims," for restoring the Muslim community to the path of righteousness (hidaya) at the time when adherence to the precepts of Islam was seriously imperiled. Al-Qashshāsh also recommends the sultan Abdallāh al-Tarjumān's account as an excellent and insightful collection of answers to the infidels and an example of everything that is virtuous. ${ }^{7}$

At this early stage of Sultan Ahmed's reign it was certainly hard to predict what the young ruler's guiding principles and impact would be. Ahmed I acceded to the throne in the middle of the Thirteen Years War that pitted the Ottomans against the Habsburgs between 1593 and 1606, which was probably perceived by al-Qashshāsh and other Muslims in

\footnotetext{
${ }^{6}$ Leiden University Library, Levinus Warner collection, Or. 432. For the sheikh's dedication see verso side of the fourth and recto side of the fifth leaf, and for the mention of translator Muhammad b. Sha 'ban's name see folio 2b. For the full description of the manuscript see Schmidt, Catalogue of Turkish Manuscripts in the Library of Leiden University and Other Collections in the Netherlands, vol. I, pp. 107-10.

${ }^{7}$ In the introduction to his translation, which follows the sheikh's dedication, Muhammad b. Sha'ban also discusses the utility of having a work on the basic principles of faith (of the so-called aqaid genre) accessible in simple Turkish language due to its potential to keep infidelity in check and correct the practices of Muslims who cannot access the works of highly learned men. Furthermore, he reflects on the dangers of distorting the meaning of the original text in Arabic through translation, indicating that the method he would employ will be to give both the original text and its paraphrase in Turkish. See Or. 432, 2 a. I thank Rashed Daher for translating this section of the introduction for me.
} 
North Africa as a highly meritorious act. Ahmed I was also a sultan who built his image and legitimacy by projecting an aura of piety and religious orthodoxy in the era when the prerogative to define and defend the correct belief and practice became increasingly politicized and contested not only in Europe but in the Ottoman Empire as well. ${ }^{8}$ Even if the sheikh's praise about the sultan's returning the Muslim community to the path of righteousness may have been premature in 1604, he would have approved of Ahmed I's later actions, such as his active diplomatic involvement on behalf of the Morisco refugees from Spain beginning in 1608, and his efforts to facilitate their post-expulsion settlement in North Africa and throughout the Ottoman territories, including Istanbul. ${ }^{9}$ According to contemporary accounts, al-Qashshāsh was the greatest patron of the Morisco refugees in Tunis, they were central to his social and political projects, and numerous in his circle of disciples. ${ }^{10}$ It is possible that by choosing al-Tarjumān's narrative as an appropriate gift for Ahmed I, al-Qashshāsh sought to highlight, in addition to his own commitment to faith and the sultan as the caliph of all Muslims, the role of Tunis, its many converts to Islam, and those who, like al-Tarjumān, chose exile and Islam over Christianity (i.e. Moriscos) in upholding the greatness of religion.

According to Míkel de Epalza's study of the manuscript traditions and dispersion of Abdallāh al-Tarjumān's work, al-Qashshāsh's 1604 commission of its translation into Ottoman Turkish, and the text's sub-

\footnotetext{
${ }^{8}$ On the process of fashioning of a Sunni religious orthodoxy and its politicization in the Ottoman Empire, which could be related to the debate on "confessionalization" in early modern Europe, see Krstić, "Illuminated by the Light of Islam and the Glory of the Ottoman Sultanate: Self-Narratives of Conversion to Islam in the Age of Confessionalization"; and Terzioğlu, "How to Conceptualize Ottoman Sunnitization: A Historiographical Discussion". For developments specifically in Ahmed I's reign see Tezcan, The Second Ottoman Empire. Political and Social Transformation in the Early Modern World, 46-78; and Krstić, "Contesting Subjecthood and Sovereignty in Ottoman Galata in the Age of Confessionalization: The Carazo Afair, 1613-1617".

${ }^{9}$ On Ottoman sultans, including Ahmed I's involvement with the Morisco issue see Temimi, Le gouvernement ottoman et le problème morisque. See also his Temimi, "Politique ottomane face à l'implantation et à l'insertion des Morisques en Anatolie"; and Temimi, "Politique ottomane face à l'expulsion des Morisques et à leur passage en France et Venice 1609-10". Additionally, see Benafri, "Endülüs'te son Müslüman kalıntısı Morisko'larin Cezayir'e Göçü ve Osmanlı Yardımı (1492-1614)".

${ }^{10} \mathrm{See}$, for instance, Turki, "Documents sur le dernier exode des Andalous vers la Tunisie"; and Pieri, "L'accueil par des Tunisiens aux Morisques expulsés d'Espagne: un témoignage morisque".
} 
sequent arrival (at an unknown date) in the Ottoman Empire marked the onset of its spread and fame in the Islamic world, where it appears to have been unknown previously. ${ }^{11}$ The earliest surviving manuscript of the Tuhfa is in fact the one from 1604 containing the dedication to the Ottoman sultan in al-Qashshāsh's own hand, which makes the story of this manuscript as well as of the actors involved in its production and their motivation particularly interesting.

We are fortunate to have considerable information about alQashshāsh's life and activities thanks to abundant contemporary primary sources about him, particularly of Tunisian provenance. ${ }^{12}$ However, it is interesting to examine how his Ottoman contemporaries viewed him. According to one of the most detailed sources on his life and deeds, the biographical dictionary of the Ottoman Halveti sheikh and poet Nev'izâde Atâî (1583-1635), al-Qashshāsh belonged to the Qadirī Sufi branch. He enchanted his followers with his miraculous deeds and claims that he was the messianic figure of the Islamic apocalyptic tradition (mahd $\bar{\imath}$ ) whose authority bridged political and spiritual spheres. He used his considerable wealth to set up pious endowments, build schools and bridges, and redeem Muslim slaves traded along the coast of North Africa. ${ }^{13}$ From other contemporary sources we learn of al-Qashshāsh's intimate involvement with the local political powers like Osman (or 'Uthmān) dey, whose control over the regency between 1598 and 1610 witnessed the reduction of the Ottoman influence in Tunis from a more direct rule by an Istanbul-appointed paşa to a nominal one. According to the sources, Osman dey married al-Qashshāsh's daughter, which legitimated his claim to power in Tunis. ${ }^{14}$ Osman dey also recruited Morisco refugees into his military ranks and like alQashshāsh aided their integration into Tunisian society. ${ }^{15}$ Not only were Moriscos numerous in al-Qashshāsh's network of disciples but one aspect of this cooperation was also financing of the corsair expeditions

${ }^{11}$ Epalza, Fray Anselm Turmeda, p. 43.

${ }^{12}$ For the background see Abdesselam, Les historiens tunisiens des XVIIe, XVIIIe et XIXe siècles, pp. 25-6; and Epalza, "Sidi Bulgayz, protector de los Moriscos exiliados en Túnez, (s. XVII)" and the literature on al-Qashshāsh cited there.

${ }^{13}$ Atâî, Hadayiku'l-hakaik fì tekmileti'ş-şakaik, pp. 652-4.

${ }^{14}$ On this relationship see Epalza, "Sidi Bulgayz", pp. 145-8. For general background on Tunisia under the Ottomans in this period see Abun-Nasr, A History of the Maghrib in the Islamic Period, pp. 170-1.

${ }^{15}$ On this issue see Temimi, “Évolution de l'attitude”, pp. 171-2. 
against Christians in the Mediterranean in which Moriscos participated and from which they profited. ${ }^{16} \mathrm{He}$ was in direct contact with Ottoman authorities in Istanbul where, as Atâî's biographical dictionary testifies, he was well known and respected by the highest dignitaries like the chief jurisprudent (şeyhülislām) Yahya Efendi (1622; 1625-1632, 16341644) even after his death. ${ }^{17}$

Epalza speculates that prior to commissioning the translation of $\mathrm{Ab}-$ dallāh al-Tarjumān's work al-Qashshāsh may have drawn on the help of a prominent Morisco intellectual and author of other polemical texts, Ahmad al-Hanafì (d. 1650?), who was familiar with the Tuhfa and who may have worked over the third section of the treatise. ${ }^{18}$ The authenticity of this section of Abdallāh al-Tarjumān's work has been cast in doubt due to misrepresentations of the Christian dogma that would be surprising coming from a former cleric but more understandable if the section had been composed by someone with a less active knowledge of Christianity. ${ }^{19}$ The section also seems to make references to the topics such as indulgences that would suggest a post-Tridentine sensibility of the author. ${ }^{20}$ These details led Epalza to speculate that a Morisco author, possibly al-Hanafī, was involved in the reworking of the Tuhfa. However, given the details that can be reconstructed of al-Hanafi's career, he may not have been the most accessible collaborator for alQashshāsh in 1604, although he was certainly aware of and used the Tuhfa in his polemical works. ${ }^{21} \mathrm{He}$ departed from the Iberian Peninsula sometime in the early 1600 s, resided for an extended time in the Ot-

\footnotetext{
${ }^{16}$ On participation of the Moriscos in Tunis in piracy and slave trade in the first half of the seventeenth century see Epalza, "Moriscos y andalusíes en Túnez durante el siglo XVII"; Bernabé Pons, "Notas sobre la cohesión de la comunidad morisca más allá de su expulsión de España"; Boubaker, "Activités économiques des morisques et conjuncture dans la régence de Tunis au XVIIe siècle".

${ }^{17}$ Atâî, Hadayiku'l-hakaik, p. 654.

${ }^{18}$ Epalza, Fray Anselm Turmeda, pp. 48-9; 166-68. See also Epalza, "Nota sobre un nuevo 'falso' en árabe, de moriscos en el exilio, antes de la expulsión general (Túnez 1603?): la pseudo-Tuhfa de Turmeda ( $3^{\mathrm{a}}$ parte)". On Ahmad al-Hanafì's career see Epalza, "Moriscos y andalusíes", pp. 293-7. On his polemical writings see Epalza, "Arabismos en el manuscrito castellano del Morisco tunecino Ahmad al-Hanafî" and Wiegers, "European Converts to Islam in the Maghrib and the Polemical Writings of the Moriscos", pp. 213-8.

${ }^{19}$ On the issue of authenticity of this section of the Tuhfa see also Álvarez, "Anselm Turmeda", pp. 184-5; Szpiech, "The Original is Unfaithful to the Translation", p. 165; and Szpiech, Conversion and Narrative, pp. 204-5.

${ }^{20}$ Epalza, Fray Anselm Turmeda, p. 360.

${ }^{21}$ Ibid., p. 49.
} 
toman Empire, where he is said to have studied in Sarajevo and Bursa, and arrived in Tunis only around 1620 where he became a key figure in the local Morisco community and later served as a Hanafi judge of Tunis (1635-8) -a major representative of the Ottoman government's tenuous influence and sovereignty in Tunisian society that otherwise adhered mostly to Maliki law. Significantly, while in the Ottoman Empire, he seems to have made an acquaintance with the future şeyhülislām Yahya Efendi who at some point allegedly invited Ahmad al-Hanafi to become the palace imam of sultan Murad IV (1623-40), the honor which he refused on account of preferring to stay in Tunis. ${ }^{22}$ However, returning to al-Hanafî 's possible role in editing the Tuhfa, manuscripts could evidently travel and be jointly commented upon by scholars based as far apart as Tunis, Istanbul and Bursa, which does not entirely exclude the possibility of his involvement in the edition that emerged in the early $1600 \mathrm{~s}^{23}$

As to the translator of the Tuhfa into Ottoman Turkish, Muhammmad b. Sha'ban, the only concrete biographical detail we learn from his introduction to the work is that he was from Ma'arrat al-Nu'mān, a city today in northwestern Syria. ${ }^{24}$ Without mentioning this fact, Epalza suggests that the translator could have been a relative of a Muhammad b. Sha'ban, who was the Hanafi imam of Tunis much later in $1097 / 1685 .{ }^{25}$ Ottoman sources, however, point to another probable candidate by the name of Muhammad $b$. Sha'ban. Nev'izade Atai gives a detailed biographical entry on a Muhammad $b$. Sha'ban from Trablus in Maghreb (Tripoli, Libya), a learned jurist who came to Istanbul in $1016 \mathrm{AH}(1607 / 8)$ and became a protégé of the chief jurisprudent Sun 'ullah Efendi, reaching the rank of a senior judge (mollā). He died in $1020 \mathrm{AH}(1611 / 12)$ leaving behind many works, among which a

${ }^{22}$ The main source on al-Hanafî’s sojourn in the Ottoman Empire and his connections to the Ottoman intellectuals is the biographical work by an eighteenth-century Tunisian author, a Hanefite of Turkish origin named Husayn Khuja (d. 1754), who relied on a variety of sources in Arabic, Persian and Ottoman Turkish. Unfortunately, it is unclear who exactly his source is on al-Hanafî’s career. See Khuja, Dhayl bashā 'ir ahl al-īmān bi futūhāat āl 'Uthmān, pp. 170-1.

${ }^{23}$ See Wiegers, "European Converts", pp. 215-218; and Levi Della Vida, "Manoscritti Arabi di Origine Spagnola nella Biblioteca Vaticana", pp. 181-4.

${ }^{24}$ Or. 432, Leiden University Library, 2 b.

${ }^{25}$ Epalza, Fray Anselm Turmeda, p. 50. 
compilation of the deeds (manāqib) of Abū 1-Ghayth b. Muhammad al-Qashshāsh. ${ }^{26}$ While it is true that this biographical entry does not make a reference to $\mathrm{Ma}^{\text {' } a r r a t ~ a l-N u}$ ' $m \bar{n}$, other details of the career and timing suggest that this may be the person familiar with al-Qashshāsh and accessible to him in 1604 in Maghreb to produce the translation of the Tuhfa. His orientation towards Istanbul and its intellectual and scholarly circles also fits well with the overall circumstances of the manuscript's production and the translator's elaborate dedication of the work to Sultan Ahmed I.

Today, the copy of this manuscript is in the University Library of Leiden where it arrived sometime after the death of Levinus Warner (1619-1665), the famous Dutch Orientalist, diplomat, and manuscript collector who seems to have acquired it in Istanbul during his residence there in the 1640s and 50s. ${ }^{27}$ Questions abound as to how this copy containing a dedication to the Ottoman sultan ended up in the hands of the Dutch Orientalist. As Jan Schmidt points out, the manuscript does not seem to have entered the imperial library because it does not bear a sultanic cipher $(t u \breve{g r} \bar{a})$ or any other marks that would suggest its being processed by the Ottoman palace or a pious endowment (vakf). On the other hand, the dedication in al-Qashshāsh's own hand in a characteristic Maghrebi (kufic) script and an ornamental plate suggest that it was intended as a present for the sultan himself.

This manuscript is one among about thousand Arabic, Hebrew, Turkish and Persian manuscripts Warner obtained through various intermediaries in Istanbul and Aleppo. His collection contains several other copies previously owned by intellectuals like Katip Çelebi and Nev'izade Atai, the historian Hasan Beyzade, as well as high Ottoman dignitaries ranging from şeyhülislām Sadeddin Efendi and the chief white eunuch Gazanfer Ağa to possibly Sultan Murad IV himself. ${ }^{28}$ By looking at Warner's manuscript collection we begin to discern a network of European, Ottoman and North African intellectuals (Muslim, Christian and Jewish) as well as various intermediaries who facilitated the exchange of information, manuscripts, translations, etc. during early

${ }^{26}$ Atâî, Hadayiku'l-hakaik, p. 552.

${ }^{27}$ On the history of Warner's collection see Schmidt, Catalogue of Turkish Manuscripts, pp. 43-44.

${ }^{28}$ Ibid., p. 44. 
to mid seventeenth century. ${ }^{29}$ Some manuscripts and translations that were copied in and exchanged among Istanbul, North Africa and various European intellectual centers are traceable to the Morisco diaspora. For instance, a Maliki legal manual by Abū Sa'īd Jalaf b. Abī l-Qāsim al-Azdī al-Qayrawānī al-Barādi ${ }^{\prime} \overline{1}$ (mid- $5^{\text {th }} / 11^{\text {th }}$ century), today found in the Biblioteca de la Real Academia de la Historia in Madrid, was translated into Spanish and written in Arabic script in Constantinople in 1606 by a certain Ali b. Muhammad b. Hader. ${ }^{30}$ More famously, the Spanish version of the Gospel of Barnabas, a text purporting to be the long-lost authentic version of the Gospel in which Muhammad's coming was prophesied by Jesus, was apparently translated from Italian into Spanish in Istanbul by a Morisco named Muștafa de Aranda some time in the first half of the seventeenth century, after which it began to circulate among Moriscos in Tunis as well as various Dutch and English antitrinitarians in Europe. ${ }^{31}$ Prior to a copy of it being purchased by Warner, Abdallāh al-Tarjumān's Tuhfa was mentioned in the 1630s in the polemical works of the North African-based Moriscos like Aḥmad al-Ḥanafĩ and Aḥmad ibn Qāsim al-Hajarī, ${ }^{32}$ both of whom had Istanbul connections. These examples shed light on the broader dynamic of manuscript exchange and circulation, which seems to have affected the destiny of the 1604 copy of Abdallāh al-Tarjumān's account on its way to and out of Istanbul.

\section{Part II. Abdallāh al-Tarjumān "meets" Mehmed b. Abdullah of Athens}

Epalza's research suggests that after al-Qashshāsh commissioned the translation of the Tuhfa into Ottoman Turkish in 1604, two manuscript families of the text containing the translation appeared in the sev-

\footnotetext{
${ }^{29}$ On this issue see also Schmidt, "An Ostrich Egg for Golius; the John Rylands Library MS Persian 913 and the History of Early Modern Contacts between the Dutch Republic and the Islamic World".

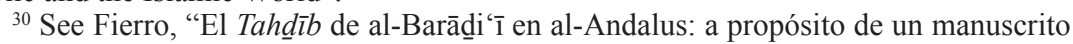
aljamiado de la Real Academia de la Historia".

${ }^{31}$ Bernabé Pons, El evangelio de San Bernabé: un evangelio islámico español, pp. 67; 21-32.

${ }^{32}$ Epalza, Fray Anselm Turmeda, p. 49; al-Hajarī, Kitāb nāșir al-dīn 'alā'l-qawm alkāfirin (The Supporter of Religion Against the Infidels), p. 216.
} 
enteenth century: the Tunisian (Maghrebi) and the Ottoman one. Other groups of manuscripts containing only the Arabic text begin to appear later, in the eighteenth and especially nineteenth centuries, throughout the Arab-speaking world. ${ }^{33}$ The second-oldest surviving manuscript of the translation is the copy today housed at the Süleymaniye Library, dated to AH 1106/1694. ${ }^{34}$ This copy, which was commisioned by the treasurer (hazinedār) Şahin Ahmed Ağa as a gift for Sultan Mustafa II (1695-1703), exhibits the characteristic features of Ottoman manuscript illumination. ${ }^{35}$ The question is what this manuscript was based on: were there copies of the Tuhfa translation other than the autograph purchased by Warner in the 1640 s or 50 s circulating in the city, or did another copy arrive from North Africa at some point during the seventeenth century and serve as the basis for the 1694 manuscript? If other manuscripts were in circulation in Istanbul soon after 1604, what was the nature of the Ottoman reception of the Tuhfa before 1694? Do we have any evidence that the text made an impact on the Ottoman audience?

What can be said with certainty is that a copy of the text was available to the Ottoman polymath Katip Çelebi, since he mentions the Tuhfa several times in his bibliographical dictionary written in Arabic, Kashf az-zunūn 'an asāmi l-kutub wa-l-funūn. It is known that Katip Çelebi's work on the dictionary progressed to the letter $h \bar{a}$ by AH $1063 / 1652,{ }^{36}$ which would mean that he would have completed his entry on the Tuhfa prior to this time. In his entry Katip Çelebi does not mention that the Tuhfa had been translated into Turkish, so it is unclear whether he had access to a copy with or without the translation. Regardless, the work was evidently known at least to some members of the Ottoman reading public by the early 1650 s, although we can only speculate about the number of circulating manuscripts.

\footnotetext{
${ }^{33}$ For an overview of the manuscript provenances and dates see Epalza, Fray Anselm Turmeda, p. 178.

${ }^{34}$ According to Epalza, the second-oldest surviving manuscript of the Tuhfa's translation into Ottoman Turkish should be the copy located in the library of the Uppsala University that dates to 1059/1649 (Epalza, Fray Anselm Turmeda, p. 175). From the relevant catalogue entry, however, it appears that this manuscript does not actually contain the Turkish translation but only the text in Arabic. Other texts of the miscellany in which the Tuhfa is found are also all in Arabic. See Tornberg, Codices Arabici, Persici et Turcici Bibliothecae Regiae Universitatis Upsaliensis, pp. 265-6.

${ }^{35}$ Süleymaniye Library, Hamidiye 719, 142 a. The manuscript later became part of the pious endowment (vakf) of Sultan Abdülhamid I (1774-89).

${ }^{36}$ See Hagen, "Katib Çelebi".
} 
However, I would suggest that the evidence of the Tuhfa's impact on the Ottoman audience soon after 1604 and prior to the 1650 s can be discerned not only by following the trace of the surviving copies of the work itself but by expanding our investigation trans-textually and even trans-communally. I therefore contend that the evidence of the Tuhfa's appeal and circulation can be found in an untitled conversion narrativecum-polemical treatise in Ottoman Turkish, written at the latest in the month of Ramazan 1034 (June-July, 1625) - the date borne by the oldest surviving manuscript found to date. Ostensibly it was authored by a certain Mehmed b. Abdullah, a former Orthodox Christian priest originally from Athens who converted to Islam in the presence of Sultan Ahmed I, presumably sometime between 1603 and $1608 .{ }^{37}$ The authorship of this account is a particularly intriguing question to which we must return. However, for the sake of convenience, in the ensuing discussion I will refer to the author as "Mehmed b. Abdullah," a Christian convert to Islam from Athens, as the narrator introduces himself in the opening sentence.

Unknown until recently and heretofore unpublished, this narrative figures as one of the key texts for understanding the social, textual and linguistic dimensions of conversion to Islam in the Ottoman Empire in general, and in the seventeenth century in particular. ${ }^{38}$ Despite significant differences between the Tuhfa and Mehmed b. Abdullah's narrative, especially in terms of length, style, and specific polemical arguments used to bolster the case of Islam's superiority over Christianity, similarities in the basic narrative framing of the authors' conversion stories are striking and hard to dismiss as a mere coincidence. As it will be argued below, Mehmed b. Abdullah's account appears inspired by the first, autobiographical part of Abdallāh b. Abdallāh alTarjumān's narrative, and possibly by some aspects of the Chapters III and IX of the polemical third part.

${ }^{37}$ I have been able to consult four copies of the narrative, the oldest of which is MS Reisülküttab 800, 153b-159b, housed at Süleymaniye Library in Istanbul and dated to the month of Ramazan 1034/June-July 1625. Other manuscripts include a copy from the month of Ramazan 1035/May-June 1626 also located in Süleymaniye Library, Ali Nihat Tarlan 144, 57b-60a; an eighteenth-century copy located in the Österreichische Nationalbibliothek under the call number N. F. 380, 227b- 231a, and (most likely) a nineteenth-century copy located in Süleymaniye Library under the call number of Giresun Yazmalar1 171/3, 46b-51b.

${ }^{38}$ I introduced and briefly analyzed this narrative in Krstić, "Illuminated by the Light of Islam"; see also Krstić, Contested Conversions to Islam: Narratives of Religious Change in the Early Modern Ottoman Empire, pp. 110-2. 
Like Abdallāh b. Abdallāh al-Tarjumān, Mehmed b. Abdullah opens his account with a sentence about his place of origin -in his case Athens- which is described as "the source of philosophical sciences" (menba'-i 'ulüm-i hikemīye). Just like the Tuhfa's author, he also begins the story with his education: he states that in this city he was raised and educated as a Christian in theological and philosophical, Greek sciences (fünūn-i Yünāniyye) ${ }^{39}$ Incidentally, we know that at the turn of the seventeenth century Athens became something of a hub for neo-Aristotelian teachings thanks to Theophilus Corydalleus (1563-1646) who studied with Cesare Cremonini in Padua and established an academy in Athens sometime in the early $1600 \mathrm{~s}$, before becoming the Director of the Academy of the Ecumenical Patriarchate in Constantinople in $1624 .{ }^{40}$ Both authors therefore seem to have shared the exposure to the Aristotelian approach to the theological curriculum. ${ }^{41}$

In a further parallel to al-Tarjumān's account, Mehmed states that early on into his education he became aware of certain contradictions and forebodings in the scriptures, which he nevertheless ignored at first. However, with God's guidance he immersed himself in the study of the Old and New Testaments as well as the Psalms only to discover that many of the verses offered definite proof of the prophecy of "that pearl of the sea of existence, the spiritual teacher of the lovers of God, that brightly shining moon, Muhammad Muștafa (peace be upon him) and confirm[ed] the eternity of his religion and sacred law." Hereafter Mehmed begins to introduce and interpret the "true" meaning of those verses from the scriptures that, according to him, announced the prophecy of Muhammad. In order to display his expert knowledge, he cites those verses in Greek but transcribes them in Arabic script with vowel signs. Following the quotations in Greek, Mehmed interprets their meaning in Turkish and argues that the traditional Christian interpretation of these verses is incorrect. While his choice of representative verses overlaps in some cases with al-Tarjumān's in the article IX of the third part of the Tuhfa that is devoted to proofs of Muhammad's prophetic character found in the scriptures, it also diverges sig-

${ }^{39}$ Ali Nihat Tarlan 144, 57 b; Reisülküttab 800, 153 b.

${ }^{40}$ See Runciman, The Great Church in Captivity, p. 222; and Podskalsky, Griechische Theologie in der Zeit der Türkenschaft (1481-1821), pp. 194-95.

${ }^{41}$ For Abdullah al-Tarjumān's educational trajectory see Epalza, Fray Anselm Turmeda, pp. 204-6; and Boase, "Autobiography", pp. 47-9. 
nificantly enough in both presentation and interpretation to suggest that, in this respect, Mehmed could have been influenced by another polemical source as well. All in all, he addresses far fewer Old Testament passages than al-Tarjumān and his discussion of the New Testament has a different emphasis.

For instance, the first verse that he discusses is Genesis 49:10, not mentioned by al-Tarjumān, stating that "The sceptre shall not depart from Judah, nor a lawgiver from between his feet, until Shiloh come; and unto him shall the gathering of the people be." Mehmed comments:

The meaning of this passage is that Jacob addresses his noble sons and says "Oh my sons, the line of prophecy and political dominion will not be cut off from you until he comes. After he arrives, they will be cut off. The whole world is awaiting his arrival."

The Christian teachers of the Torah claim falsely that when Jacob says "he will come," he is in fact referring to the promised arrival of Jesus.

Mehmed explains that "the divers in the sea of meanings" understand that Jacob could not have had Jesus's arrival in mind because, even after his arrival Israel continued to exist and be prosperous, so it is obvious that its political dominion was not cut off. Mehmed then explains that this happened only after the coming of Muhammad. ${ }^{42}$

Next Mehmed turns to the interpretation of the verse he says he found in the Torah. He is apparently referring to Deuteronomy 18: 1819 , which is also cited by al-Tarjumān. However, what Mehmed is in fact citing is Acts 3:22-23 that paraphrase these verses, which suggests his greater familiarity with the New than with the Old Testament: “... A prophet shall the Lord your God raise up unto you of your brethren, like unto me... And it shall come to pass, that every soul, which will not hear that prophet, shall be destroyed from among the people." ${ }^{3}$ Here he explains that Moses, to whom the verses are ascribed in Deuteronomy, promised the arrival of a prophet who would not be of Israelite lineage but would come "from the branch of a tree of a different garden" and would be born "of a father and a mother," unlike Jesus.

As the proof of Muhammad's coming he next cites the verses from Psalm 72, which is also used by al-Tarjumān, although the latter's se-

${ }^{42}$ Ali Nihat Tarlan 144, 58 a-b; Reisülküttab 800, 155 a.

${ }^{43}$ Ali Nihat Tarlan 144, 58 b; Reisülküttab 800, 155 b-156 a. 
lection of precise lines to include is slightly different. ${ }^{44}$ These verses state: "In his days shall the righteous flourish; and abundance of peace so long as the moon endureth. He shall have dominion also from sea to sea, and from the river unto the ends of the earth. They that dwell in the wilderness shall bow before him; and his enemies shall lick the dust...Yea, all kings shall fall down before him.” Mehmed comments on this as follows:

In other words, God says to David (peace be upon him): “After you I shall send a prophet bearing a sacred law the lights of whose seal of prophecy will scatter rays to the east and west. The first of his community who will follow him will be of the Arab people. Those obstinate ones who oppose him will be overcome and abased. The rulers of the world will make his law a collar on the neck of obedience. His religion and law will last until the Day of Judgment." As before, the band of opponents engages in nonsensical interpretation and once again say that it refers to Jesus. Since the reply to them is very apparent, there is no need to go into particulars. ${ }^{45}$

Then Mehmed switches to the discussion of the Gospels:

Let it be known that the writers of the Gospels were four of the apostles who were falcons fettered by unbreakable bonds to the company of Jesus (peace be upon him) and whose inspired words they registered in the pages of the Gospels. Consequently the Gospels consist of four parts known after their authors as the Gospels of John, Matthew, Luke and Mark. ${ }^{46}$

Unlike al-Tarjumān, Mehmed does not immediately dismiss the validity of the Gospels. In fact, unlike al-Tarjumān and other Muslim polemicists, he does not engage in attack on any particular aspect of Christian dogma, such as the concept of Trinity or Jesus's divinity. Perhaps most surprisingly, given the importance of the notion of paraclete (Gr. "helper," "comforter," "advocate") in both al-Tarjumān's and Muslim anti-Christian polemical tradition, Mehmed does not discuss this issue at all. He makes only a passing reference to the Gospel of John where paraclete - the term interpreted by Muslim polemicists as a code word for Muhammad — is mentioned. ${ }^{47} \mathrm{He}$ comments:

${ }^{44}$ Epalza, Fray Anselm Turmeda, p. 486.

${ }^{45}$ Ali Nihat Tarlan 144, 58 b-59 a; Reisülküttab 800, 156 b.

${ }^{46}$ Ali Nihat Tarlan 144, 59 a; Reisülküttab 800, 156 b-157 a.

${ }^{47}$ The sections of the Gospel of John (Chapters 14 -16) where Jesus foretells the coming of Paraclete to his disciples were some of the earliest parts of the New Testament to be 
The Gospel of John contains the verbal description of Muhammad, but since deviant Christians followed an interpretation of these words that was unacceptable, they fell into the pit of rebellion and were unable to save their necks from the deception of rebellion. ${ }^{48}$

Rather, he chooses to bolster his argument that Jesus announced Muhammad's arrival in the Gospel by relying on what he introduces as a passage from the Gospel of Matthew. However, what he is in fact citing is a combination of John 1:15 and Luke 3:16, both of which paraphrase Matthew 3:11. This, along with other previously mentioned substitutions of the verses he is making, suggests that the author may not have had the actual text of the Bible in front of him while composing the text but rather wrote from memory. This is how he argues his case:

The meaning is that Jesus says: "The one who will come after, who was created before me, I am not worthy to untie the strap of his sandal." It is well known that in explaining these passages the nonsensical Christians and the envious Jews make claims that identify the bearer of the prophetic mission spoken of in these verses either [for the Christians] as Jesus or [for the Jews] as the awaited Messiah, citing numerous untenable premises to support their deficient opinions... Advocating their claims in this way, they say that these devotion-causing words about the acceptance of servitude and bonds of submission that are implied in the untying of the strap of the sandal were uttered by John (the Baptist) about Jesus. However, it is not concealed from those who wear [lit. cover themselves] with the cloak of veracity and justice that the apostles' stream of belief was free from the rubbish of polytheism and obstinacy. The above-mentioned passage, being the words of Jesus, was recorded in the pages of the Gospel and has circulated among them from that time until now. So it is obvious that their recourse to such nonsensical interpretation is simply the lack of anything to lean on. ${ }^{49}$

This is a significant departure from the traditional line of argumentation by Muslim polemicists with Christianity, since it suggests that the Gospels and the evangelists were free of polytheism and that it was

"translated" into Arabic. Ibn Isḥāq (d. c. 767), for instance, refers to John 15:26: "But when the Comforter ( $\pi \alpha \rho \alpha ́ k \lambda \eta \tau o \varsigma)$ is come, whom I will send unto you from the Father, even the Spirit of truth, which proceedeth from the Father, he shall testify of me." Muslim polemicists claimed that this word should be read as periclytos, which translates as "the praised one," or Ahmad in Arabic, which is one of the names of Muhammad. See Griffith, "The Gospel in Arabic: An Inquiry into its Appearance in the First Abbasid Century", pp. 137-43. On paraclete in Turmeda's account see Epalza, Fray Anselm Turmeda, pp. 212-4, 480-4.

${ }^{48}$ Ali Nihat Tarlan 144, 59 a; Reisülküttab 800, 157 a.

${ }^{49}$ Ali Nihat Tarlan 144, 59 a; Reisülküttab 800, 157 a. 
the interpretation of the text rather than the text of the Gospels themselves that was faulty.

Seeking to relate to the reader the process by which his spiritual and intellectual feverishness was increasing over time and how troubled he was becoming by the gradual realization of the truth of Muhammad's prophecy contained in the Scriptures, before every next verse Mehmed describes the increasingly troubled state of his consciousness. These introspective sections are enhanced by Persian verses composed specially for the account or drawn from such classics of Persian poetry as Jalāl ad-Dīn Rūmī's Mathnawī, Hilālī Chaghatāyī's Shāh u Darwīsh and Nizāmī Ganjavì's Khusraw u Shīrīn..$^{50}$ All verses contain imagery of an intense spiritual struggle, conjuring up the notion of the truth that is hidden behind a sequence of veils, and gradual illumination of Mehmed's soul by the light of Islam. The poetic vocabulary of the Persian Sufi tradition in fact pervades the entire text: the central figure of the truth seeker, i.e. the future convert Mehmed, is represented as a diver for the pearls in the sea of truth, while the verses that he sees as implicit announcements of Muhammad's prophecy are described as a pearl necklace and Muhammad himself as the largest, most valuable pearl of creation. By weaving in the imagery of light central to Sufi tradition, as well as various animal- and garden-related metaphors typical of the Ottoman divan poetry, the text aims to build up the author's credentials as a cultural broker versed in both non-Muslim scriptural tradition and the high register of the Ottoman literary idiom.

Although in the text Mehmed's agitation caused by understanding the scriptural verses' deeper meaning seems to reach the crescendo after his discussion of Mathew 3:11, and his realization that Islam is the true religion begins to haunt him unbearably, he writes that he still could not summon the courage to break with the customs and rites of his ancestors and reject "the girdle of unbelief." He therefore sets out on a journey around the "lands of Rum" (which could denote Ottoman European domains but possibly also Anatolia) with the plan of seeking out the most knowledgeable priests who could resolve his dilemmas and settle the matter of the verses' meaning once and for all. He describes his journey as going from town to town and village to village

${ }^{50}$ I thank my colleague Ferenc Csirkés for identifying the provenance of these verses. 
and participating in debates with various clergymen but without a desired outcome. Finally, he decides to go to Rome:

While I was in this state of bewilderment it occurred to me that all the learned men from the ranks of the infidels are in great Rome, that is also known as the Red Apple, the place of abode of the Pope who resolves all doubts. So I went there with the purpose of resolving the matter. I resided there for four years and diligently inquired into the thoughts of the erring sects. I was amazed to see all of them wandering in the wilderness of error.

The fact that an Orthodox Christian from Athens would seek clarification on religious issues in Rome should not surprise us. As it was mentioned above, in the early seventeenth century a neo-Aristotelian and a graduate of the university in Padua, Corydalleus, founded the academy of Athens. Already beginning in the 1570s Greek-speaking youths from the Ottoman Empire had the option of studying at the Greek College in Rome established by Pope Gregory XIII with the expressed purpose of promoting Catholicism among the Orthodox. The presence of Franciscan and Jesuit missionaries (the latter since the late sixteenth century) in the Ottoman lands, particularly in Rumeli, Constantinople, and along the Aegean coast, also led to an increased exposure of the Ottoman Orthodox Christians to the teachings of the post-Tridentine Catholic church. Moreover, since the second half of the sixteenth century and well into the seventeenth, the Orthodox Patriarchs in Constantinople themselves continuously wavered among professing allegiance to the Pope, embracing one of the Protestant denominations, or keeping to the Orthodoxy that was itself being redefined at this time as a consequence of the polemical dialogue with Islam, Calvinism, Lutheranism and post-Tridentine Catholicism. ${ }^{51}$

One of the cornerstones of the Tridentine reforms -the sacrament of penance and its main protagonist, the confessor- in fact features prominently in the text. Mehmed writes:

One of the current practices of the infidels is that they choose from among themselves a knowledgeable and experienced priest who is advanced in years and appoint him to a certain place. Whoever has doubts, whether religious or worldly, reveals them to him and gets his reply. He in turn does not disclose the questions he is asked, even if the matter is a capital offense; and if he does, he is removed from that office. This priest who can be trusted for advice is called in Greek pneumatikos and in Latin confessor.

${ }^{51}$ On this issue see Krstić, Contested Conversions to Islam, pp. 121-42. 
Interestingly, in Part III, Chapter III of the Tuhfa we also find a discussion of the sacrament of penance and the role of confessors in Latin Christendom, particularly in the city of Rome, that prompted scholars to speculate that this section was a later addition to the text. After giving a similar explanation of the confessors' function like Mehmed, Abdullah al-Tarjumān dismisses them as sinful and no more worthy of absolving one of sins than an average person, and confession as no more than a way for the priests to enrich themselves. ${ }^{52}$ While Mehmed does not voice this exact criticism, his dismissal of the confessors and their competence is implicit in his final critique of the Christian priestly establishment's blind clinging to error.

Mehmed says that he considered the fact that talking about Islam openly could be dangerous and therefore decided to seek out a confessor to share his concerns privately. Interestingly, the notion that the truth seeker might face danger and even death for bringing up the fact that the scriptural verses point to Islam as a religion that guarantees salvation figure in both accounts. ${ }^{53}$ The episode of the conversation with the priest/confessor is the culmination of both al-Tarjumān's and Mehmed's narrative, serving as a direct prelude to their respective conversions to Islam. Mehmed writes:

I went to that priest's place of seclusion, showed him the above-mentioned texts, and began to expound the heart-burning secret that was fixed in my nature. When he saw the deep trouble and confusion in me, he heaved a throat-burning and house-melting sigh, drew his head into the shirt-neck of perplexity and stood there for a while. Then gazing at me with the eye of longing he said: "Oh sorrowful one of the community of Jesus! If you remain constant in showing respect to the Christian rite with its ancestral rituals, the interpretation of the ancients, constantly repeated, is well known... Otherwise, if you turn in the direction of error and follow the siren call of personal interpretation $(i c t i h \bar{a} d)$...the plain meaning of these letters and words is manifest and there is no possibility of other meanings. Accordingly, it is known and supported by scriptural authority, without regard to defects [in the argument?], who is referred to in these passages. For the preservation of the ancestors, refuge was sought in the margin of interpretation. If your desire is to respect the ancestral cloak, which is required by the human sense of honor, then stay with that. Otherwise, removing the curtain of custom in the lands of the Franks and unfurling the banner of the religion of Islam will condemn you to sacrificing your head. Do what you think is right!"

${ }^{52}$ Epalza, Fray Anselm Turmeda, pp. 360-67.

${ }^{53}$ Ibid., pp. 218-21. 
Upon hearing that, Mehmed concludes that the entire Christian ecclesiastical establishment is guilty of leading the people into heresy and confusion. ${ }^{54}$

In the final act of this spiritual drama, which again parallels al-Tarjumān's account, the author writes:

I immediately turned the reins of intention in the direction of Islam. Passing over hill and dale, rolling up the stages of my journey, I arrived at the center of the circle of the pillar of Islam, the seat of the caliphs, Constantinople. Through the intercession of the teacher of the late Sultan Ahmed Han (may God grant him mercy and forgiveness) I entered the imperial council. That is to say, under the watchful imperial gaze of the late Sultan Ahmed Han himself, I received instruction in Islam in the glorious divan and my name became Mehemmed [Muhammad] by the sultan's own designation. After that, I exchanged my priestly garment for the splendid sultanic robe of honor and my Christian locks were shaved by the Ahmedian razor. I became a torch kindled by the light of religion and a slave in the court of the sultanic state. Finally, I did not know how to write Turkish language; my utmost desire was to withdraw into a corner of the imperial harem and occupy myself with learning the Qur'ān and Muslim worship, so that eventually I would become laden with presents appropriate to my status. ${ }^{55}$

Like al-Tarjumān, who benefitted from the intercession of the court doctor Yusuf al-Tabib, Mehmed claims that he relied on the mediation of the sultan's hoca, most likely the powerful Mustafa Efendi (d. c. 1608) who was not only the royal tutor but early on in the young sovereign's reign his co-regent as well. ${ }^{56}$ The date of Mustafa Efendi's death would then figure as the terminus ante quem for the dating of Mehmed's conversion. It is important that both authors claim to have converted in the presence of the sultan and with the sovereign's active participation in the ceremony, ending their accounts with the description of the beneficence bestowed upon them as a result.

I have argued elsewhere that this triangulation among the convert, the Sultan and God in Ottoman self-narratives of conversion since the mid sixteenth century is a reflection of the Ottoman participation in a broader early modern age of "confessionalization," characterized by a tighter politico-religious integration as a basis for community and state

${ }^{54}$ Ali Nihat Tarlan 144, 59 b-60 a; Reisülküttab 800, 159 a-159 b.

${ }^{55}$ Ali Nihat Tarlan 144, 60a; Reisülküttab 800, 159 b.

${ }^{56}$ On Yusuf al-Tabib see Epalza, Fray Anselm Turmeda, pp. 224-26. On Mustafa Efendi, Sultan Ahmed I's tutor, see Börekci, "Factions and Favorites at the Court of Sultan Ahmed I (r. 1603-1617) and His Immediate Predecesors", pp. 95-108. 
building. ${ }^{57}$ As the sixteenth century progressed, the Ottomans moved towards a stricter definition and enforcement of a Sunni orthodoxy that became central to their state and dynastic legitimacy, partly in response to political and religious rivalry with the Catholic Habsburgs and Shi'a Safavids. ${ }^{58}$ With religion and politics intertwined in this new way, conversion to Islam ceased to be an event of local importance and became tantamount to an act of pledging political allegiance to the Ottoman sultan.

As recent research suggests, the ritual of conversion in the imperial palace as well as circumcision by surgeon on the premises and dispensation of the new clothes and sometimes governmental positions to the converts became formalized precisely during Ahmed I's time. ${ }^{59}$ This new visibility of the conversion ritual was part and parcel of the overall imperial policy that was increasingly emphasizing sultanic piety and religious orthodoxy as the key aspect of the Ottoman dynastic legitimacy at the time when it was challenged by a variety of internal and external actors - a trend that would intensify towards the middle of the seventeenth century and take on various forms of social disciplining previously unseen in the Ottoman context. ${ }^{60}$ One could argue that, in light of the fact that Abdallāh al-Tarjumān's conversion narrative highlights the relationship among the convert, his new religion/God, and the sultan/patron, it is perhaps not accidental that it attracted particular attention and began to be disseminated only in the early seventeenth century, in the new atmosphere in which self narratives of conversion become weapons in the multi-directional religio-political struggle within and between Christendom and Islamdom.

While, as it was shown above, Mehmed's narrative was not a close copy of al-Tarjumān's Tuhfa, it nevertheless displays three crucial par-

${ }^{57}$ See Krstić, Contested Conversions to Islam, pp. 12-16, 98-120. The question of whether or not "confessionalization" necessarily had to involve the state has been much debated since the concept was first suggested in the context of early modern Habsburg history, in the late 1970s/early 1980s. On this issue see Lotz-Heumann, "The Concept of "Confessionalization". A Historiographical Paradigm in Dispute".

${ }^{58}$ On this issue see Terzioğlu, "How to Conceptualize"; and Burak, "Faith, Law, and Empire in the Ottoman 'Age of Confessionalization' (Fifteenth-Seventeenth Centuries): the Case of 'Renewal of Faith"'.

${ }^{59}$ Krstić, "Illuminated by the Light of Islam," p. 58.

${ }^{60}$ Baer, Honored by the Glory of Islam; Terzioglu, "Where Ilm-i hal Meets Catechism: Islamic Manuals of Religious Instruction in the Ottoman Empire in the Age of Confessionalization". 
allels to it: 1) it opens with an auto-biographical section discussing the place of origin and theological education leading to doubts about the convert's ancestral religion that strikingly resembles al-Tarjumān's introduction; 2) it continues with a polemical part that displays the convert's knowledge of the scriptures in the language spoken by his Christian community (in this case Greek); 3) it ends with the scene of conversion to Islam in the presence of the Muslim ruler (in this case, the Ottoman sultan) and with references to the imperial patronage that followed upon conversion. Furthermore, like al-Tarjumān's account, it features the scene of encounter with a knowledgable priest whose interpretation of the scriptural verses causing the future convert's confusion unequivocally points to the true religion and constitutes the decisive moment in the latter's intention to embrace Islam. The existence of this scene and its identical function in both accounts by itself strongly suggests a close intertextual relationship.

Although there is no conclusive proof that Mehmed (or another possible editor of this work) read the Tuhfa, circumstantial evidence strongly suggests that this was the case. This evidence is based primarily on the study of medieval and early modern self-narratives of conversion to Islam among which al-Tarjumān's account stands out for its novel characteristics. Most notably, in the Tuhfa the narrative of conversion moves, in Ryan Szpiech's words, "from its position as an afterthought to its prominence as the opening frame of the entire discussion to follow." ${ }^{61}$ Rather than constituting an appendix to the polemical work that precedes it, which was the case with earlier known self-narratives of conversion to Islam, in al-Tarjumān's text the author's personal background is directly connected to the polemical content. This notion that conversion to Islam is the culmination of one's personal experience of search for the truth is structurally even more perfected in Mehmed b. Abdullah's account. Here the polemical section is not elaborated separately, as in the Tuhfa, but integrated into the narrative that culminates in the scene of conversion to Islam. Compared with the only earlier Ottoman self-narrative of conversion to Islam, the polemical treatise of Murad b. Abdullah written in 1556/7 (to which

${ }^{61}$ Szpiech, Conversion and Narrative, p. 207. Szpiech has argued that al-Tarjumān's account resembles the medieval Christian models of conversion narrative by Augustine and Petrus Alfonsi much more than other, earlier narratives of conversion to Islam. See ibid., pp. 201, 208. 
an autobiographical section is added ten years later and can be described as an "afterthought"), ${ }^{62}$ Mehmed b. Abdallāh's as well as subsequent Ottoman self-narratives of conversion (to be discussed below) closely follow in terms of narrative structure and polemical images and tropes the model set by the Tuhfa, which was re-discovered in the early seventeenth century. Based on this, it would appear that the Tuhfa, whether in Arabic or with its translation into Turkish, was familiar to some readers in the Ottoman Empire already by 1625 and made a considerable impact on the developing Ottoman polemical genre of selfnarratives of conversion to Islam.

\section{Part III. The questions of authorship and genre in the formation of an Ottoman corpus of polemical texts}

The final comment in Mehmed's account, on his lack of facility with "Turkish language", together with the fact that the two oldest manuscript copies located so far give the name of a certain kadl (judge) Mahmud bin Hasan as the text's mü'ellif raises questions about the account's authorship. In modern Turkish, the term mü'ellif denotes the "author, writer, editor or compiler" and thus implies some sort of authorship of the text. What was meant by the same term in seventeenthcentury Ottoman Turkish is more equivocal and some scholars have recently argued that it does not necessarily imply originality but may stand for a "creative mediation" or arrangement of the text's sections. ${ }^{63}$ It is certainly possible that in the more than ten years that passed between his conversion and writing of the account sometimes after 1617, Mehmed the convert -assuming he is a real person-mastered the Persianate sociolect of the elite Ottoman literary culture and authored this account himself. However, one could also allow for a possibility that Mehmed the convert shared his expertise in Greek language and Christian scriptures with a Muslim author versed in Ottoman literary style to coproduce an elaborately ornate and learned account that was not

${ }^{62}$ For a detailed analysis of this narrative and its relationship to other Muslim selfnarratives of conversion see Krstić, "Illuminated by the Light of Islam"; and Krstić, Contested Conversions to Islam, pp. 79-80, 98-120.

${ }^{63}$ On this issue see Paker, "Translation, the Pursuit of Inventiveness and Ottoman Poetics: A Systemic Approach”. 
easily accessible in its full linguistic scope to many of his contemporaries. Like al-Tarjumān's account, this narrative may therefore also be the work of multiple editors who, nevertheless, maintained the fiction of a personal conversion story in a cultural and religious climate in which such a genre was increasingly becoming meaningful. Such partnerships between the convert insufficiently experienced in the sacral language and/or literary idiom of the new religious group he joined and a cultural impresario willing to promote his cause with the new audience are evident in other contemporary conversion narratives from nonOttoman contexts as well. ${ }^{64}$

Given Mehmed b. Abdullah's/Mahmud b. Hasan's highly ornate literary and multi-lingual style it is perhaps surprising that this polemical conversion narrative was popular enough to be copied in the centuries after its composition. One indication of who the audience for this account may have been is the textual context in which it is found in the existing copies. For instance, the copy from $1035 / 1626$ is found in a miscellany (mecmu' 'a) with twelve other works of poetry by wellknown, mostly Istanbul-based poets of the early seventeenth century. ${ }^{65}$ The copy from $1034 / 1625$, on the other hand, is in a mecmú ' $a$ with a work on the deeds of the Prophet and another work of religious nature. ${ }^{66}$ Later on, however, we see a different context as the account begins to appear together with other Ottoman polemical narratives that boasted translation of the scriptures, their transliteration into Arabic script, and a personal conversion story. In fact, one could argue that by the early eighteenth century a "corpus" ${ }^{" 67}$ of Ottoman self-narratives of

${ }^{64}$ See, for instance, the narrative of "Don Juan of Persia" in Le Strange, Don Juan of Persia: A Shi 'ah Catholic, 1560-1604, p. 299. See also Mazur and Shinn, "Introduction: Conversion Narratives in the Early Modern World”, especially p. 429.

${ }^{65}$ These are Nev'i Mehmed Efendi Ma'alkaravi (d. 1598)'s Netā'icü'l-Fünūn, Veysi Üveys b. Mehmed Alaşehri (d. 1627)'s Vakl'a-nāme (or Hāb-nāme) and Divan, Nef'i Ömer b. Muhammed Erzurumi (d. 1635)'s Divan and Kasä'id, Riyazi Mehmed b. Mustafa Birgili (d. 1645)'s Kasā'id and Sākî-nāme, Kara Çelebi-zade Abd el-Aziz b. Hüsam ed-dîn (d. 1657)'s Gülşen-i Niyāz, Hakanî Mehmed Bey (d. 1606)'s Hilyetu'n-Nebī, Ruhi Osman Bagdadi (d. 1605)'s Terkīb-i Bend, and Fa'izi Kaf-zade Abd el-Hayy (d. 1621)'s Leylā ve Mecnūn. See Ali Nihat Tarlan 144, Süleymaniye Library.

${ }^{66}$ See Reisülkuttab 800, Süleymaniye Library. The mecmū' $a$ contains another two works entitled Menākıb-ı Seyyidü'l-Mürselīn and Tırāz-l zeyl-i sühan. The names of the authors are not given.

${ }^{67}$ See note 76 below. 
conversion emerged showcasing their authors' ability to argue the case of Islam by refuting Jewish and Christian scriptures in their original languages, making this issue central to their authenticity and "value" as converts.

In addition to the translation of al-Tarjumān's account into Ottoman Turkish and Mehmed b. Abdullah's account, this "corpus" included a text in Ottoman Turkish entitled Keşfü'l esrār fi ilzämi'l-Yehūd v'el$a h b \bar{a} r$ [Unveiling the Secrets of Compelling the Jews and the Rabbis (to accept the proofs of Islam)], ostensibly by a Jewish convert named Yusuf ibn Ebi Abdi'd-Deyyan, that can be dated to 1651 and of which seven copies have been identified so far. ${ }^{6}$ This text begins with a firstperson conversion narrative that bears interesting parallels to Mehmed's and al-Tarjumān's accounts in that it emphasizes the author's education in traditional rabbinical learning, his growing doubts from his childhood to his mature age about the truth of the Jewish scriptures, the evidence of Muhammad's prophecy that he eventually finds in the verses of the Torah that leads to his rejection of his ancestral religion and conversion to Islam. While we can certainly find the same tropes of the converts' education and portrayal of their conversion as a rational decision based on scriptural proofs in other earlier Jewish narratives of conversion to both Islam and Christianity, it is the preeminence of this motive in both contemporary European and Ottoman conversion narratives that is of particularly concern here. The polemical part of the account is a translation into Ottoman Turkish of Ahmed Taşköprüzade's anti-Jewish polemical tract written in Arabic in the sixteenth century, although the author does not acknowledge this fact in the text. ${ }^{69}$

Furthermore, in a move similar to Mehmed's, the author transcribes the verses from the Hebrew Bible in Arabic script and translates them into Ottoman Turkish, which, as Judith Pfeiffer points out in her study of this narrative, may be the earliest translations of the Torah into Ot-

\footnotetext{
${ }^{68}$ For a detailed discussion of this text and translation into English of its autobiographical part see Pfeiffer, "Confessional Polarization in the $17^{\text {th }}$-Century Ottoman Empire and Yusuf Ibn Ebi 'Abdü'd-Deyyan's Keșfü'l-esrāa fì ilzāmi'l-Yehūd ve'l-ahbārr'. See also Krstić, Contested Conversions to Islam, pp. 114-16.

${ }^{69}$ Pfeiffer, "Confessional Polarization," p. 25. For the edition of Taşköprüzade's text with an English translation see Schmidtke and Adang, "Aḥmad b. Muștafā Ṭashkubrīzāde's (d. 968/1561) Polemical Tract Against Judaism”.
} 
toman Turkish. Given that the narrative also features references to intraJewish polemics and authors not cited in Ottoman anti-Jewish polemical narratives before, it seems that in this case we are also dealing with a creative author/editor who drew on his own experiences (or of that of another convert) in addition to other texts. For instance, in the oldest surviving manuscript from AH 1088 (1677/78) the name of the supposed author of the text, Yusuf ibn Ebi Abdi'd-Deyyan, is embedded into the beginning of a story reported by a third person, a certain Kepenkcizade (or Kepenekcizade) Sinan, a Jew who is said to have converted to Islam on the basis of the proofs he found in the Hebrew Torah. ${ }^{70}$ Pfeiffer suggests that the editor(s) may have experimented with a variety of available texts. It is possible that these texts included alTarjumān's and Mehmed's narratives that were already known to the Ottoman reading public by the mid seventeenth century and began to figure as models for writing a self-narrative of conversion cum religious polemics.

Significantly, in another important parallel, the author of this account also refers, albeit somewhat obliquely, to his conversion in the presence of the sultan and to the latter's subsequent patronage. He states: "I made it my responsibility and special duty to pray for the prolongation of the bounteous patronage of the shadow of God on earth under whose wings I was sheltered. I was assiduous in making known that my conversion was based on virtue and sincerity." He also specifies "that 'gate to the refuge of happiness' (i.e., the Sultan) elevated me to the might and loftiness of the right course." tween sultanic legitimacy and conversion to Islam in the seventeenth century has already been discussed above; however, it is important to emphasize that in the context of what Marc Baer has termed "turn to piety" that affected not only the sultan and members of his family and government but also 'religious specialists' of different social and educational backgrounds, ${ }^{72}$ non-Muslims and Jews in particular became targets of various initiatives to correct the morals of the society and

${ }^{70}$ See MS. Or. 2050/2, Oriental Collection, "SS Cyril and Methodius" National Library, Sofia. On this issue also see Pfeiffer, "Confessional Polarization," pp. 27-9.

${ }^{71}$ Pfeiffer, "Confessional Polarization," p. 43.

72 This 'turn to piety' and suggestions on how the Muslim community should be disciplined affected various Sufi authors as well. On this issue see Terzioğlu, "Where Illm- $i$ hal Meets Catechism". 
purge it of elements of unbelief. ${ }^{73}$ Yusuf's insistence on the "sincerity" of his conversion appears particularly important in light of other contemporary instances of conversion for reasons of fear or opportunity, like in the case of the famous Jewish messiah Sabbatai Zvi who converted to Islam under duress in 1666.

The final text belonging to this "corpus" of Ottoman self-narratives of conversion cum polemical treatise is the so-called Risāle-i Islämiyye [Treatise on Islam] by the celebrated founder of the first Ottoman printing press in Arabic script, İbrahim Müteferrika (c. 1670-1745), which was completed in 1710. Although it has been believed that this narrative survives in a single autograph copy, new research suggests that there are at least five manuscripts of it in various libraries in Turkey, some of them misidentified and mis-catalogued, which raises the possibility that further examples might surface. ${ }^{74}$ Although he does not explicitly refer to either al-Tarjumān's or Mehmed's accounts, Müteferrika's indebtedness to them in terms of narrative framing and inspiration for his polemical text is undeniable. His account opens with the story of his education in theology in the Transylvanian city of Kolozsvár (today Cluj-Napoca in Romania) where he became licensed as a priest (most likely of Calvinist denomination). Unlike his predecessors, however, who are satisfied with referring to the well-known verses from the scriptures as the basis for their discovery of Muhammad's prophecy and eventual conversion, Müteferrika goes a step further and credits his conversion to the verse from the Old Testament that was supposedly forbidden to the uninitiated seminary students but to which he gained access and which contained conclusive proofs of Muhammad's prophecy. He cites both this verse that was supposedly removed from the canonical version of the Christian scriptures as well as other com-

\footnotetext{
${ }^{73}$ On the impact of the Kadizadeli movement on the Jewish community see Baer, Honored by the Glory of Islam.

${ }^{74}$ So far only the autograph copy housed in Süleymaniye Library, Esad Efendi 1187, has been known. Further copies I was able to identify include Süleymaniye Library, Bağdatli Vehbi 2022, from 1175/1761-2 and another undated copy that is misidentified as "Terceme bazı âyeti'z-Zebūr ve't-Tevrāt ve'l-İncīl" in the same library under the call number of Esad Efendi 7. Necdet Yılmaz, the editor of a new edition of M. Esad Coşan's study and transliteration of Risāle-i Islämiyye, identified two further copies of the manuscript and published sample facsimile pages from them in the appendix to the book (348-56): one is located in Türk Tasavvuf Müsikisi Vakfi Ö. Tuğrul İnançer Kütuphanesi (YK-İ), no. 1, and yet another one is in Süleymaniye Library, in the collection of Esad Efendi, number 3442. I thank Baki Tezcan for bringing this new edition to my attention.
} 
monly known verses from the Bible in Latin, transcribing them in Arabic script and paraphrasing their meaning, like Mehmed. In this way, Müteferrika not only takes the traditional Muslim polemical argument about the alteration and corruption of Christian and Jewish scriptures

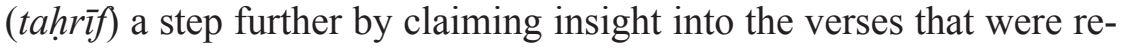
moved from the Bible, but also completes the corpus of the Ottoman polemical texts cum conversion narratives by contributing a text with transliterations and translations into Ottoman Turkish from Latin, along with Mehmed's from Greek and Yusuf's from Hebrew. ${ }^{75}$ Although in terms of framing and polemical goals it corresponds with other Ottoman conversion-cum-polemical narratives, Müteferrika's account should also be studied in depth for its own merits, not least of all for its interesting eschatological view of the international religio-political developments and the Ottoman Sultan's messianic role in them. The narrative is dedicated to Sultan Ahmed III and we again have to keep in mind the issue of patronage as a motivation for producing the text.

That these texts were related to each other seems to have been recognized by the readers and copyists who in some cases copied them back-to-back in their scrapbooks (mecmī ${ }^{6} a$ s). ${ }^{76}$ However, it is striking that from this corpus of Ottoman narratives the one that won the day as the most popular, and that was published on several occasions, was none other than Abdallāh al-Tarjumān's account. In terms of surviving manuscripts in Turkish libraries, there are at least fourteen copies of the Tuhfa with Ottoman translation and another six in Arabic only. ${ }^{77}$

${ }^{75}$ Baki Tezcan recently established that Müteferrika was using the translation of the Torah and the Psalms by Immanuel Tremellius and Franciscus Junius, and of the New Testament by Theodore Beza, which means that he probably availed himself of the $1648 \mathrm{Am}-$ sterdam edition of the Biblia Sacra. See Tezcan, "İbrâhîm Müteferrika ve Risâle-i İslâmiyye".

${ }^{76} \mathrm{At}$ least three mecmū 'as combining these texts survive. For instance, in one scrapbook from the eighteenth century (Süleymaniye Library, Bağdatli Vehbi 2022) we find alTarjumān's Tuhfa in Arabic (copied in 1787/8), Müteferrika's Risāle-i Islāmiyye (copied in 1761/2) and Yusuf İbn Ebi 'Abdü'd-Deyyan's account (copied in 1763/4). Another nineteenth-century scrapbook (Süleymaniye Library, Giresun Yazmaları 171) contains the Tuhfa with the translation in Ottoman Turkish, Yusuf b. Ebi Abdüdeyyan's account and Mehmed b. Abdullah's account. Yet another one (Süleymaniye Library, Giresun Yazmaları 102) contains the Tuhfa with the Ottoman translation and Yusuf İbn Ebi 'Abdü'd-Deyyan's account, among other texts.

${ }^{77}$ Epalza had counted eleven manuscripts, in both Ottoman Turkish and Arabic, housed in Turkey (see his Fray Anselm Turmeda, pp. 173-4) but modern databases allow for a more comprehensive search that yields a higher number. 
These numbers are supplemented by the availability in the Turkish libraries of the copies of three published editions in Arabic, from 1873 (London), 1895 (Cairo) and 1904 (Cairo), and the two editions published in Ottoman Turkish in Istanbul, in 1874 and 1886. Interestingly, however, instead of being based on Muhammad b. Sha'ban's translation from 1604 that was available in the manuscript collections throughout the capital, the first Ottoman Turkish edition from 1874 is a translation of the Arabic edition from 1873 that was published in London at the height of a global Muslim-Christian debate raging among scholars and missionaries from the British Isles to India, with a significant participation of the Ottoman intellectuals. ${ }^{78}$ This new Ottoman translation was prepared by the two professors at the Mekteb-i Mülkiyye (The Imperial Civil School that later became Imperial School of Political Science), Emiroğlu Mehmed Said (d. 1918) and Mehmed Hac1 Zihni (d. 1911), the latter being particularly wellknown in the contemporary European Orientalist circles for his work on Arabic grammar and literature..$^{79}$ The publication dates of the two Ottoman editions, from 1874 and 1886, coincide with the boom in the production of antiChristian polemical tracts, especially during the era of Sultan Abdülhamid II (1876-1909), by Ottoman Muslim authors from throughout the empire, both in reaction to the increased presence of various Christian missionaries (both Protestant and Catholic) and the changing position of the non-Muslims in the social life of the Ottoman realm. ${ }^{80}$

The possibility that Abdallāh al-Tarjumān's text was brought to the attention of the two Ottoman translators because it was published in Arabic in London and made available at booksellers' stands in Istanbul, ${ }^{81}$ rather than because of its long-term popularity within the Ottoman Empire itself, is intriguing and meaningful. It would point to the unpredictable patterns of textual transmission and dissemination

${ }^{78}$ Johann Strauss suggests that the editor behind this London edition, who signs himself as "Murad İstanli," was possibly the third baron Stanley of Alderley, Henry Edward John Stanley (d. 1903), who converted to Islam and was famously pro-Ottoman. He was also familiar with both Arabic and Turkish. See Strauss, "Müdafaa' ya Mukabele et Mukabele'ye Müdafaa: une controverse islamo-chrétienne dans la presse d'Istanbul (1883)", p. 68, n. 5 .

${ }^{79}$ See ibid., p. 67, n. 4. On this translation also see Epalza, Fray Anselm Turmeda, pp. 52-3, where the translator is identified as "Abdallah Bey."

${ }^{80}$ Strauss, "Müdafaa'ya"; Rank, "Disputing Religion".

${ }^{81}$ Ibid., p. 67, n. 9. 
that are not necessarily "intra-cultural" or vertical, as we might often expect, but also lateral and cross-confessional. Muslim literati could obviously sometimes be equally if not more estranged from their Muslim predecessors than from their non-Muslim contemporaries. If we allow for the fact that the "age of confessionalization" was a much broader phenomenon than the European and Middle Eastern historiographies of the early modern era would have us think, this should not surprise us. However, while the transmission of texts and compatibility of narrative strategies points to common conceptual frameworks and translatability of religio-political sensibilities in parts of early modern Christendom and Islamdom, it is important to keep in mind that these texts were used precisely to draw and redraw new confessional boundaries and delineate difference rather than underscore sameness.

\section{Appendix. Transliteration of Mehmed b. Abdullah's Narrative}

$57 \mathrm{~b}$

Risāle-i garībedir ki ahbār-i Nasārā'dan biri İslām şerefi ile müşerref olup Incīl ve Tevrāt ve Zebūr'da hazret-i risāletin hakkında vāki' olan nusūsi cem' idüp tercüme itmişdir. ${ }^{82}$

Bu 'abd-1 sādikü'l-i'tikādün maskat-1 re'si ve menşe'-i vücūdı menba'-i 'ulūm-i hikemīye olan şehr-i Atina olup, merāsim-i meslūkdāşte-i kudemā-y1 Yūnāniyye henüz meskūk-geşte-i nakd-i kabul-i ${ }^{83}$ rahābīni olup, bu bende-i nāçizlerinün dahi şi'ār-1 vücūd-i 'adīmü’t-

Note on transliteration: the text is transcribed according to the rules of modified Modern Turkish, which means that only long vowels are marked, as well as letters 'ayn (') and hamza (').

Sigla for the manuscripts used: A = Ali Nihat Tarlan 144, 57b-60a, Süleymaniye Library, Istanbul; R = Reisülküttab 800, 153b-159b, Süleymaniye Library, Istanbul; V = N. F. 380, 227b-231a, Österreichischer National Bibliothek, Vienna; G = Giresun Yazmaları 171, 46b-51b, Süleymaniye Library, Istanbul. The basis of the critical edition are the two oldest manuscripts, R and A, dated to Ramazan 1034/June-July 1625 and Ramazan 1035/May-June 1626, respectively, although A is privileged for its more complete text (see the facsimile). Important differences with other manuscripts are indicated in the footnotes. I am immensely grateful to Prof. Dankoff for his suggestions and corrections of the transcript and translation of the text.

${ }^{82}$ The introductory sentence in R says: “Atınalu kapuçı Habību'llāh evsāfın Tevrāt ve Incīl ve Zebūr'(d)a görüp îmāna geldügidir." V and G do not have an introduction.

${ }^{83}$ R: "nakd-i rahābīni". 
temȳ̄zleri ${ }^{84}$ tırāz-i dīn-i Nasrāniyye ile mutarraz bulunup nuhle-i Nasrāniyye ile intihāl ve pāy-i şu ūr ve tedeyyunum şikāl-beste-i milleti 'Īseviyye olmag̉la cānib-i āhara harekete mecāl olmayup hasb-i i'tibārü'd-deyyār bidāyet-i 'ahd-i lazimü'l-cehd-i tufūliyyetimden gāyet-i eyyam'ul-beyz-i kühūlete varınca nakd-i himmet-i kāmilü'l'iyārımı masārıf-i 'ulūm-i mesīhīyye tahsīline sarf ve zimām-i kesbi hāizü' l-i'tibār-1 ihtiyārımı cānib-i tekmīl-i fünūn-i Yūnāniyye'ye 'atf idüp resīde-i 'ahd olan evrāk-i kühne[de ${ }^{85}$ batā[ri] $\mathrm{k}^{86}$ felāsifenin dahi hilāl-i sutūr-i sa 'bü'l-'usūrında niçe akvāl-i acībe ve emsāl-i pür 'iberi garībe'ye ${ }^{87}$ nazar-1 şu'ūr ve ittılā' $1 \mathrm{~m} \mathrm{ki}{ }^{88}$ ta'alluk itdi. ${ }^{89}$ Defe'ātle rehābīn-i şöhret-şi ${ }^{‘} a ̄ r-i \quad$ diyār ve esākife-i ${ }^{90}$ intihā-disār ${ }^{91}$ ile tarh-endāz-i ${ }^{92}$ meclis-i mübāhase olup hila'-i făhire-pūş pesend ve imtiyāz olmuşumdur.

Fe-li'llāh al-hamd ki kā'id-i ahkām-i kazā ve kader, 'ālem-i 'ibdā' ve fitret'de rakabe-i vücūd-i selāmet-i mev'ūdimi rıbka-i kabūl-i İslām ile mutavvak itmek ile hüsn-i kabūl-i tevfîk virüp wa'llāhu yahdī man yash $\bar{a}^{\prime} u^{93}$ delāletiyle asl-1 asīl-i matālib-i 'āliye olan ahkām-i dīn ve tarīkati ve ā'māl-i lāzimetü’l-imtisāl-i şerī'atı muhteviye olan kütüb-i semāviyye ve nusah-i dīniyye tetebbu' $1 n^{94}$ sevk-i taleb-i hātır ${ }^{95}$ erzānī kıldı. Bu i'tibār ile gitdikçe mutezāyidü'ş-şuġl ve'l-tetebbu' olup 'āmme-i Yehūd ve Nasārā sohbetinde müteffikü'l-ārā' oldukları Tevrāt ve Zebūr ve İncīl'de ki tā'ife-i Firenc beyninde lisāni-i Latin'de mutedāvel ve gürūh-i Nasārā miyānında zebān-1 Yūnān'a tercüme ile müsta'meldür, ol dürr-i deryā-yı hestī, bedraka-i hüdā-perestī, māh-i sipihr-i safā hazret-i Muḥammadu'l-Mustafā 'aleyhi's-selām'ın sıdk-i nübuvvetini nātık ve bakā-yı din ve şerí'atini musaddık niçe nusūs-i kāti'atü'l-işkāl ve nukūl-i sādıkatü' l-me'āle musārif olup

${ }^{84}$ R: "temeyyīzleri”".

${ }^{85}$ R: "kühnede".

${ }^{86}$ R: "batārik".

${ }^{87}$ V, R: "acībe" and "garībe" are transposed.

${ }^{88} \mathrm{~V}$ : does not have "ki" here.

${ }^{89} \mathrm{~V}$, G: "itmişdür ki".

${ }^{90} \mathrm{R}$ : "esāfike".

${ }^{91} \mathrm{~V}$ : "ve esākife-i intihā-disār" is missing.

${ }^{92} \mathrm{~V}$ : "ve esab"iyeyi ile".

${ }^{93}$ The complete verse from Qur'ān 2, 213; 24, 46 (cf. 10, 25; 6, 39) is "wa-[A]llāhu yahd̄ man yashā'u ilā sirātin mustaqìmin" ("For God guides whom He will [to a straight path]"). I thank Prof. István Ormos for identifying the verse.

${ }_{94}$ End of $153 \mathrm{~b}$ in R.

${ }^{95}$ End of $46 \mathrm{~b}$ in $\mathrm{G}$. 
58 a

girān hāb-i zulmet-i cehāletden b̄̄-dār ve sermest-i sahbā-yı zalālet iken huşyār oldum. Bu mukaddime zikr-i nusūsdan mukaddem lāzimü'zzikr olmaġin bast olunur ki aksām dahi zāhirden vesātat-i lisān-i melek ile ve emāret-i melik ile ki hātır-i melik denilur dahi zāhirun bu iki kısmı esnāf-i ${ }^{96}$ keferenin müsellemleri olmayup ancak ilhām-i rabbāni ile kalb-i cāzimü'l-beyān-1 nebīye tebedd̄i iden kısmına kā'illerdir ve ra'yi ictihād-ı nebī ile sādır olan dahi bātına mā'illerdür. Meğer ki nefs-i neb̄̄ye mahsūs maslahat içün melek tevassut ide hazret-i Cibra'̄̄l 'aleyhi's-selām'un Zekeriyyā 'aleyhi ezkā't-tahāyā hazreretlerine tebşīr-i veled-i sālih içün nuzūli gibi Tevrāt' da bulunan nusūsdur ki zikr olunur: ippon kai anabaten erripsen eis thalassan ${ }^{97}$ manzūm-i rişte-i sutūr-1 Tevrāt olan 'ukud-i leāli-i Museviyye' dendür ki şukkagüşa-y1 'alem-i sabr ve īsār olan ${ }^{98}$ Hazret-i Eyyūb (Job) 'aleyhi's-selām nigehbān-1 genc-i nübüvvet iken bu durer-i girān-bahāyı

'alā tarīki'l-1̄sā[1]'99 ihdā-yı ümmet buyurup Hazret-i Mūsā 'aleyhi'sselām dahi tekye- zede-i 'asā-yı nübüvvet iken lāyiha-i nebeviyyesinden sudūr idüp muhākī-i ümmet olmuşdur. Ma'ānası bizüm hefevāt [ve cerāyim] ile güzerān iden ömrümüz ${ }^{100}$ şiddet-i tūfān-1 şitāda endāhte-i bahr-i cūşān nā-peydā kenār olan şahs-i nā-tuvāna benzer ki keştī ve keştībān-1 meded-res necāt olmazsa garka-i girdāb-1 helāk olması mukarrerdür. Pes bizi dahi lücce-i hefevāt-1 ${ }^{101}$ mahālik-i mecāzīden ve varta-i mehāvif-i ${ }^{102}$ tūfān-i ma'āsīden tahlīse keştī-i şerī'at ve keştībān1 bahr-i hakīkat-şināsdan lābüd'dür ki selāmet-resan-1 sāhil-i necāt ola. Muhakkikān-i Nasārā ve Yehūd sefine-i Nūh 'aleyhi's-selām zāhirde numūdār-i hakīkat mefhūm olmak üzre temsīlen īrād itmişlerdür. Bu bendeleri dahi çün bu kelimāt-i hikmet-āmīzin dürer-i ma'ānīsini riştei [fehm ve] ${ }^{103}$ kabūle çekdüm āb-i hidāyet rīhte-i rūy-i hāb-ālūd olup

${ }^{96}$ End of $227 \mathrm{~b}$ in $\mathrm{V}$.

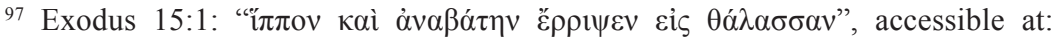
http://biblehub.com/sepd/exodus/15.htm [accessed on May 15, 2013]. I thank Prof. Robert Dankoff for identifying this verse.

${ }^{98}$ End of 154 a in R.

${ }^{99} \mathrm{~V}$, R: "īsāll”.

${ }^{100}$ V, G: "hefevāt ve cer?yim ile güz ?r1 iden ömrümüz"; R: "hefevāt ve cerāyim ile güzerān iden ömrümüz"; end of 47 a in $\mathrm{G}$.

${ }^{101}$ R: "lücce-i mahalik-i hefevāt ve mehāzīden".

$102 \mathrm{~V}$ : "ve garindan ve vartana".

${ }^{103}$ V; R: "rişte-yi fehm ve kabule". 
rakde- ${ }^{104}$ gafletden uyandım ve keştī ve keştībān tecessüs ${ }^{105}$ lāzime-i zimmet-i himmet bilüp gavta-hār-i lücce-i taleb ve tafakkud olup serāpā-yı tayy-i sahā'if-i ${ }^{106}$ Tevrāt içün semend-i sebuk-seyr-i tab 'ime irhā-yı 'inān-1 tetebbu' idüp mahall-i āharda bu nakli dahi buldum ki zikr olunur: ouk ekleipsei archōn eks iouda kai ègoumenos ek tōn mērōn autou eōs an elthē ta apokeimena ${ }^{107}$ autō kai autos prosdokia ethnōn. ${ }^{108}$ Bu nakl dahi sahā'if-i Tevrāt'da mersūme-i yera'a-i Mūsā 'aleyhi's-selām'dur ki hazret-i Ya‘kūb 'aleyhi's-selām evlād-i emcādına ${ }^{109}$ şīrāze-i bend-i mecmū'a-i vasiyyet oldukda nigāşte-i safha-i hātıraları ve gümaşte-i 'uhde-i tezkīrleri kılınup Hazret-i Musa 'aleyhi's-selām dahi hikmet-efşān-1 ${ }^{110}$ resālet iken mülheme-i gaybiyyesinden kudūm-1 behcet-lüzūm-i seyyid-i 'ālemden mujde-resān1 ümmet olmuşdur. Ma'nāsı budur ki Hazret-i Ya'kūb 'aleyhi's-selām evlad-i kirāmına hitāb ider ki: "Ey benüm og̉ullarım, sizden nübüvvet ve saltanat munkati' olmaz mādāmki ol ${ }^{111}$ gelecek gelmeye, ol geldikden sonra sizden nübüvvet ve saltanat ${ }^{112}$ munkati' olur. Cümle 'ālem anun kudūmına muntazarlardur." Esākife-i ${ }^{113}$ Tevrāt-hvān-1 Nasārā bu kelāmin tahkīkinde Ya'kūb 'aleyhi's-selām'in "gelecek" didügi

$58 \mathrm{~b}$

mev'ūd (promised) ü'l-kudūm Hazret-i ${ }^{114}$ 'Īsa 'aleyhi's-selām'dır diyü iddi'ā-yı bātıl iderler. Lākin gavvāsān-1 bahr-i ma'ān̄i bu dürri berāverde-i nutk itmişlerdir ki Hazret-i Ya'kūb 'aleyhi's-selām'in “ol geldikde sizden nübüvvet ve saltanat munkati' olur" kaydı vişāh-i gerden-i kelām-1 sadākat-nizāmı olan ${ }^{115}$ mudde'āları sıhr-pezīr-i butlān olup beste-zebān olurlar. Hazret-i 'Īsa 'aleyhi's-selām'ın zamān-1

${ }^{104}$ V: "zühde-yi gafletden".

${ }^{105} \mathrm{R}$ : "tahassusini".

${ }^{106} \mathrm{R}$ : "safhāt".

${ }^{107}$ End of $154 \mathrm{~b}$ in R.

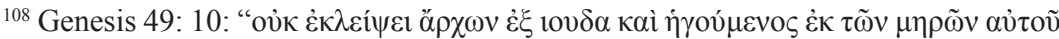

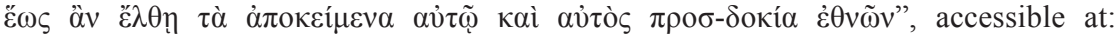
http://sept.biblos.com/genesis/49.htm [accessed on May 20, 2013]

${ }^{109} \mathrm{R}$ : "kiramine".

${ }^{110}$ R: "ifşā-i".

${ }^{111} \mathrm{~V}$ : "Resūl".

${ }^{112}$ End of $47 \mathrm{~b}$ in $\mathrm{G}$.

${ }^{113}$ R: "esafike".

${ }^{114}$ End of 228 a in V.

${ }^{115} \mathrm{R}$ : "olicak". 
nübüvvetinde henüz devletmendān-1 İsrā'̄̄lī huşāre-ç̄in-i mā'ide-i saltanat ${ }^{116}$ ve tūtī-i sebz-minkār-1 zīnet-serāy ${ }^{117}$ şeker-hvāy-1 hükūmet olup peyvend-i feysal-yāfte-i nübüvvetleri bāz-i beste-i 'ahd idi. Berīn takdīr vukū'-i inkıtā'-1 nübbüvet ve saltanat mukarrer ve müyesser olmadug̀ı zāhirdür. Bergeştegān-1 tīh-i zalāl 'anede-i Yehūd dahi bu sevādın tebȳizinde Hazret-i Muḥammad 'aleyhi's-selām ancak kavmına meb'ūs olup muntazarü'l-kudūm-1 'āmme-i 'ālem olan sāhib-i devlet henüz kadem-nihāde-i 'ālem-i şehādet olmadı, intizār-i 'ālem kemākān ber-karārdır diyü da'vā-yı bātıl iderler. Lākin tevcīh-i müdde'āda mutāraha-i efkār tahkīk iden hakk-guyān rikāb-i devlet-i İsrā'īliyye munhali 'ü'l-vişāh-i 'izzet kılınup nihāl-i ser-sebz-i Ismā'îlī nişānde-i bāg-i risālet olıcak kayd-1 sābık mefhūmi üzre İsrā'iliyye'den rişte-i nübüvvet ve saltanatın takarrur-1 inkıtā' 1 müstelzem tahakkuk-i nübüvvet-i Hazret-i Muhammed 'aleyhi's-selām olduġ̀ zāhirdir. Anların henüz intizārları kemāl-i inkār ve fesād-ı kārlarına şāhiddür. Beyt: Kasd-i işān cüz siyeh-rūȳi nebūd/ Hayr-i dīn key cüst tersā ve Yehūd. Pes bu naklın mefhūmi hayāle bend-i suver-i garībe olup tahakkuk-1 risālet-i Muhammediyye gitdikçe bu 'abd-i vāhilerine īrās-i hulecān itmekle tazā'if-i tettebu'a bādi olup ${ }^{118}$ sevk-i ilāhī ile bu nakl dahī Tevrāt'de buldum ki zikr olunur: ...prophètēn umin anastēsei kurios o theos ek tōn adelphōn umōn ōs eme autou estai de pasa psuchê" ${ }^{119} \bar{e} t i s$ ean mè akousè tou prophètou ekeinou exolethreuthèsetai ek tou laou. ${ }^{120}$ Bu nass dahī çemen-pīrā-yı riyāz-i sahā'if-i Tevrāt'dur ki Hazret-i Mūsā 'aleyhi's-selām Benī İsrāầil'e hitāb ider ki Hakk te‘āla hazretleri buyurdi ki "karındaşlarınuzdan ${ }^{121}$ bencileyin bir peygamber ba's itse gerekdür, her kim anun emrine muhālefet iderse anun istīsāli ve intikāmi bana lāzım olur” diyü buyurmuşdır. İddi ‘ā-yı Tevrāt dahi iden dālle-i Nasārā

116 End of 155 a in R.

117 R: "zīnet-serāları".

118 End of 48 a in G.

119 End of $155 \mathrm{~b}$ in R.

${ }^{120}$ Despite indicating that he is about to cite from the Old Testament, the citation is actually from Acts 3:22-23: “...

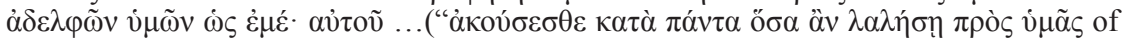

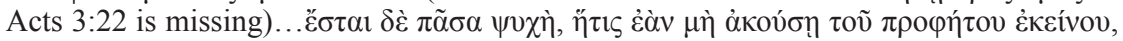

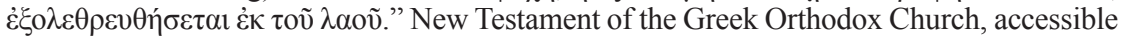
at: http://goc.biblos.com/acts/3.htm [accessed on May 10, 2013]. What the author has in mind when he says that the verse is from the Old Testament is the analogous passage from Deuteronomy 18:18-19.

121 V: "karındaşlarından". 
ol mev'ūdü'l-ba's olan sāhib-i şevket Hazret-i 'Īsa 'aleyhi's-selām'dır diyü da'vā-yı bātıl iderler. Lākin mū-şikāfān-i tedkīk bu vech üzre makāmı tahkīk itmişlerdür ki Hazret-i Musa 'aleyhi's-selām'ın kelāmi mu'ciz-nizāmında vāki" olan "karındaşlarınuzdan" 'ibāreti ol mev'ūdü'l-ba's olan nebīi 'ālī-mikdār İsrā'îl'’ tebār olmayup ${ }^{122}$ sinv-i devha-i bāğ-1 dīger olmaġi iktizā ${ }^{123}$ ve "bencileyin" lugatiyle işāreti kendi gibi peder u māderden tevelludini īmā ider. Ve nass-i mezkūrın "her kim emrine muhālefet iderse istīsāli bana lāzim olur" zīveri ile tahallīsi muktezā-yı nesh-i āyīn-i me'lūfları olmag̉la zamn-i tahakkuk1 muhālefetde va'īd-i şerīr-i gāyetü'l-istīsāl ile mev'ūd olmuşlardır. Bu takdīrce hazret-i 'Īsa olmaduġ 1 müte'ayyin ve butlān-1 müdde'āları mütebeyyindür. Ba'd ez-ān sevdā-y1 'akl-fersā-yı Muhammedī beni aşufte-dil ve muncezibü'l-hātır idüp. Beyt: ser-i sevdā-yi tu ender seri mā mì-gerded/ tu bi-bīn der ser-i şūrìde çihā mī-gerded ${ }^{124}$ kemīngāhi nazarda dil-i gil-beste-i cünūn ile gavgā-yı 1ztırāb-i derūn dā'iye-hīz-i tettebu'-1 Zebūr olup bu nakl-i kāti' 'ü'l-işkāli dahī anda buldum ki zikr olunur: ${ }^{125}$ anatelei en tais èmerais autou dikaiosunē kai plēthos eirēnēs eōs ou antanairethēe è selēnē kai katakurieusei apo thalassēs ēōs thalassēs kai apo potamou eōs peratōn tēs oikoumenēs enōpion autou propesountai aithiopes kai oi echthroi autou

59 a

choun leixousin... kai proskunēsousin auto pantes oi basileis panta ta ethne. ." 126 Ya'ni Hakk te'āla hazretleri dahi tarīkiyle Hazret-i Dāvūd 'aleyhi's-selām'a buyurur ki: "Senden sonra bir peygamber-1 sāhibşerī'at ba's itsem gerek ki envār-i mühr-i nübüvveti pertev-endāz-1 şark ve garb olup evvel ittibā' iden ümmeti kavm-i 'Arab'dan olup semt-i 'ināda sülūk iden 'anede ve muhālifîn makhūr ve zelīl ola ve padişāhān-

${ }^{122} \mathrm{~V}$ : "olmagin".

${ }^{123}$ End of $228 \mathrm{~b}$ in $\mathrm{V}$.

${ }^{124}$ End of 156 a in R.

${ }^{125}$ End of $48 \mathrm{~b}$ in $\mathrm{G}$.

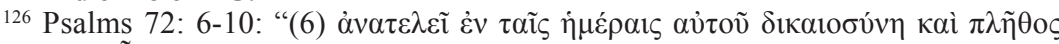

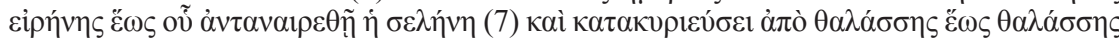

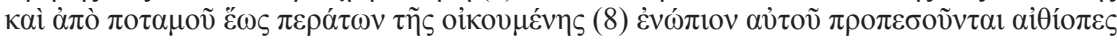

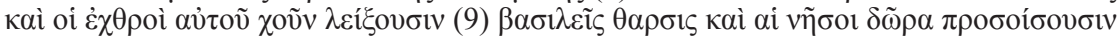

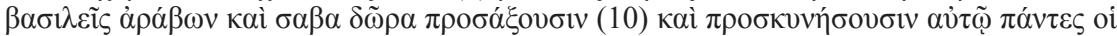

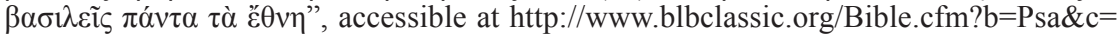
$72 \& \mathrm{t}=\mathrm{LXX}$ [accessed on May 12, 2013] 
i cihān şerī'atını rıbka-i rakabe-i gerden-i itā'at idüp ila yevmi'l-kıyām dīn ve şerī‘ati bāki ola.” Zümre-yi muhālifīn ke-l-evvel herze-yi te'vīle i'tinā idüp yine murād-i hazret-i 'İsa 'aleyhi's-selām'dır dirler. Cevābları katı zāhir olmag̉in tafsīle hācet yokdur. Ma'lūm ola ki ketebe-i İncīl havāriyūndan dört kimesnedir ki lā-yenkatı' peyvend rasīnü'l-'akd-i mulāzemetleri bāz-1 beste-i meclis-i hazret-i 'Īsa 'aleyhi's-selām olmagile sudūr ${ }^{127}$ iden kelimāt-i mülhemesini sebt-i sahāif-i İncīl itmişlerdür. Binā'en 'aleyh İncīl dört k1t'a olup her kıt'anun kātibi kendiye nisbet ile ma'lūm ola ki biri Yuhannā, biri Mattā, biri Luka, biri Markos'dur. Pes kit'a-i Yuhannā hilye-i făhire-i Muhammedīyi muhtevī olup kec-tab'ān-1 Nasārā hāric-i hadd-i kabūl fahvā-yı fesād-şumūle zāhib olmag̉la fütāde-i çāh-1 tugyān olup gerdenlerin ${ }^{128}$ gill-i gā'ile-i 'isyāndan tahlīse mecālleri yokdur. Kit'a-yi Mattā dahi kudūm-1 'izzet-lüzūm-1 hazret-i Muhammad 'aleyhi's-selām ve 'azim-i şān seyȳ̄d-i 'ālemi mufsih bu nakl-i kāti'ül-'urūk-1 muhālifīni muhtevīdir ki zikr olunur: o opisō mou erchomenos emprosthen mou gegonen oti prōtos mou ēn...ou ouk eimi axios lusai ton imanta tōn upodēmatōn autou. ${ }^{129} \mathrm{Ma}$ 'nāsı hazret-i 'Īsā 'aleyhi's-selām buyurur ki "Ol ki benden sonra gelse gerek ${ }^{130} \mathrm{ki}$ benden evvel halk olunmışdır, ol kimesnenin ben kabkabı bāgini çözmek hidmetine lāyik degilim" dimekdir. Pes ma'lūmdur ki nusūs-i sābıka tahkīkinde jājhāyān-1 Nasārā ile hased-verzān-1 Yehūd tevcīh-i müdde ‘ā itdikce mansūsu'l-ba's ve mevzū'u'l-bahs olan vucūd-1 nübüvvet-şi āri kimi hazret-i 'Īsa 'aleyhi's-selām' dır, kimi henüz muntazar-ü'l-kudūm'dur diyü tervīc-i ra'y-i kāsır içün niçe mukaddemāt-i fāside tertīb itmişler idi. Hāla hazret-i ‘'̄sā 'aleyhi's-selām çün ${ }^{131}$ bu ferīde-i manzūmetü'ssıdkı gevher-hāne-i kudsiyyesinden berāverde-i tabakçe-i nutk olup ${ }^{132}$

${ }^{127}$ End of $156 \mathrm{~b}$ in $\mathrm{R}$.

${ }^{128}$ R: "gerdenlerini".

${ }^{129}$ Although the author implies that he is referring to Matthew 3:11, in line 13 he is

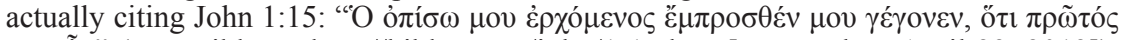

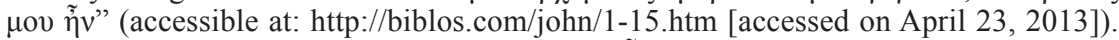

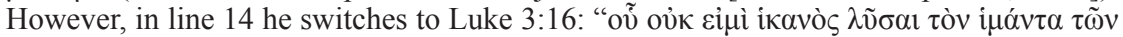

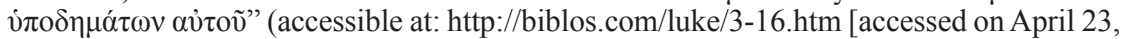

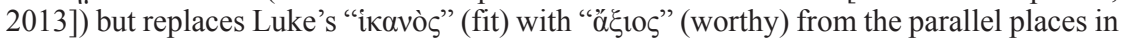
John 1:27 or Acts 13:25. I am grateful to Professor István Ormos for helping me resolve the confusion over the author's mixed citations.

${ }^{130}$ End of 229 a in V.

${ }^{131}$ End of 157 a in $\mathrm{R}$.

${ }^{132}$ R: idüp; V: “olunup". 
silk-i beyāne çekdi, gürūh-i muhālifīne $A l-\bar{n} n a$ hashasa al-haqq ${ }^{133}$ dağdag̉ası gālib olup her biri kelb-i me’būr gibi harāşīde-i gülū olup bāng1 tevcīhe mecālleri kalmayup ancak inkār ve fikirlerinde ${ }^{134} 1$ srār idüp tervīc-i müdde'āda bu vechle tehyīc-i kadem tevcīh iderler ki bu kelāmi sadākat-fercām ki ribka-i rakabe-i hidmetkāri kabūliyle hidmet-i halli şirāk-i na'leyni mutezammindir Hazret-i Yahyā'dan hazret-i 'İsā 'aleyhi's-selām hakkında sādır olmuşdur dirler. Lākin durrā'a-pūşān-1 sıdk u insāfa hafī degildür ki havāriyyūnun cūybār-1 i'tikādları hāşāki şirk ve 'ināddan 'ārī olup, nass-1 merkūmı kelām-i hazret-i 'Īsā olmak üzre sebt-i sahāif-i İncīl idüp ilā'l-ān beynlerinde dāhil-i hadd-i tevātürdür. Pes anların bu makūle herze-i te'vīle ta'vīlleri mahz 'ademi itkā ${ }^{135}$ oldug̀ 1 zāhirdür. ${ }^{136}$ Beyt: Yek̄̄ sad geşt sevdāyī ki būdem/ zi hadd bügzeşt gavgāȳ ki būdem. Bu hārhār-i 1ztırāb-1 azürdesi bu nusūs-i müctema'ayı vird-i zebān-1 cān idüp im‘ān-1 nazar ile tasavvur-1 hāl itdikce gördüm ki suver-nümā-y $1^{137}$ mutahayyilede

cilveger olan ebkār-i me‘ānīsi cümleten nāmzed-i nübüvvet-i hazret-i Ahmed̄̄ 'aleyhi's-salāt ve's-selām ve hacle-i hafā-yı sutūrından minassa-nişīn zuhūr olān 'arāyis-i netāici mu'ānik-i gerden-i risālet-i' ${ }^{138}$ (Hazret-i) Muhammadi 'aleyhi's-salāt ve's-selām olup nihān-dāşte-i kelimāt-i rāzdāri olan cevāhir-i esrāri süfte-i evsāf-ı Mustafaviyye olmag̉la gitdikce izdiyād-i teyakkun peydā idüp şāhid-i mahabbet-i Islām mir'āt-i mucellā-yı tab'imde cilve-nümā olmag̉a başladı. Lākin bi'lkülliye āyīn-i dirīn-i me'lūfì terk ve ferāg ve zünnār-güsil-i ${ }^{139}$

$59 \mathrm{~b}$

küfr olmag̉la yeksere nūr-i İslam'la efrūhte-çerāg olmag̉a cesāret idemeyüp bu kārin husūl-1 fercāmın diyār-i Rum'un meşāhīr-i rehābini ile istişāre'ye havāle itdüm. Beyt: Çü āyed müşkilī pisş-i hıredmend / ki z'ān müşkil şeved der kār-i $\bar{u}$ bend / küned 'akl-i diger bā 'akl-i hod yār / ki tā der hall-i ān gerded mededkār / zi yek şem'-eş negīred nūr hāne / fürū zed şem '-i dīger der miyāne. Egerçe hāmil-i şerr olan delili hayr olmaz, lākin esnā-yı munāzarada zuhūr-i hakk gālibü'l-ihtimāl

\footnotetext{
${ }^{133}$ Qur'ān 12:51.

${ }^{134}$ V, R: "küfrlerinde".

${ }^{135}$ R: "inkār".

${ }^{136}$ Here only A has "ba'd za (zilkade?)".

${ }^{137} \mathrm{~V}$ : "suret-nümā".

${ }^{138}$ End of $49 \mathrm{~b}$ in G; end of $157 \mathrm{~b}$ in R.

${ }^{139}$ V: "zünār-i küfr güsiste".
} 
olup sited-1 ${ }^{140}$ ittihāz itdükleri herze-yi te'vīle ta 'vīl ve i'tinā iderler ise bīhūde inkārlarina istidlāl müyesserdür. Hātırasiyla sāmān-1 'azīmeti devr-i memālik-i Rum'a tevcīh itdüm. Ve şehr be-şehr karye be-karye gezüp her kanda 'ilm u fenn ile meşhūr ve müte'ayyin pāpās ve ruhbāna ki mulākī oldum tarh-endāz-1 meclis-i munāzara olup nice k1l ve kāldan sonra bil'āhara keşf-i mācerā ve izhār-i mā-fî'l-azmār itdüm. Kimi "Peder ber peder ülfet-i āyīn-i dīrīneyi terk-i rehīn su'ūbetdır" diyüp, kimi tavāhir-i ${ }^{141}$ nusūs ile mülzem ${ }^{142}$ olup

müte' arrız-1 redd ve kabūl olmayup ${ }^{143}$ kimi "Risālet-i Muhammediyye bu nusūs-1 kāti'atü'l-işkāl ile fî'l-hakīka mustedille ve meczūmedür, nihāyet hetk-i perde-i hafā mütevakkıf-i hüdā-yi Hudā'dır" diyüp her biri hayret-zede-i esrār-i hafiyye olmagiile ${ }^{144}$ fürū beste-dem görülmekle ${ }^{145}$ mezīd-i teşviş-i bāle bādī olup ${ }^{146}$ perde-i ber-endāz-1 küfr olmag̉a ikdām idemedüm. Beyt: Gitmedi jeng-i keder-i āyinne tab 'ımdan / ölmedı gitdi hayf çehre-nümāyi dildār / bāg̀-i ma 'nīde açılmadı gül-i maksūdum / sa y ile nahl-i fezā-yi emelim virmedi bār / hayf pervāza gelüp bāz-i sepīd-i himmet / itmedi kebk-i merām-i dil-i sad derdi şikār / kaldı mestūr-l 'aceb hacle-i istignnā'da / bikr-i ma 'n̄̄-i murād itmedi 'arz-i dīdār. Bu hayret istilāsiyle medhūş ve mütefekkīr iken esnāf-i keferenün mecma'-1 dānışverānı ve müşkil-küşā-yı küll olan pāpānün makarr ve mekāni olan Rumiyye-i kubrā ki Kızıl Elma dimekile ma'rūf ve meşhūr'dur hātıra-i hutūr idüp anda dahi istikșāf-1 hāl içün vardım ve dört yıl mıkdārı sākin olup tecessüs-i zamā'ir-i firak-i dālle itdüm, cümlesin ser-geşte-i tīh-i zalāl görüp mütehayyir oldum. 'Ākibet āyīn-i kefereden bu vaz' cārīdır ki mābeynelerinden bir mu'temidü'l-kavl ve mu'takidü'l-'amel rāhib-i sāl-horde ve mezheb-şinās ihtiyār idüp bir mahalle nasb ve ta'yīn iderler ki her kimin dīn̄̄ ve dünyevī müşkili var ise ana keşf idüp cevābin ala. Ve ol dahi kendüye su'āl itdükleri husūs-1 katl ve siyāseti dahi mūcib ise kimseye keşf itmeyüp saklıya, keşf itdügi takdīrce ${ }^{147}$ merdūdları olmak ma ‘hūdleridir. Pes eyle olsa ol rāhib-i mü’temenü'l-istişāreye zebān-i

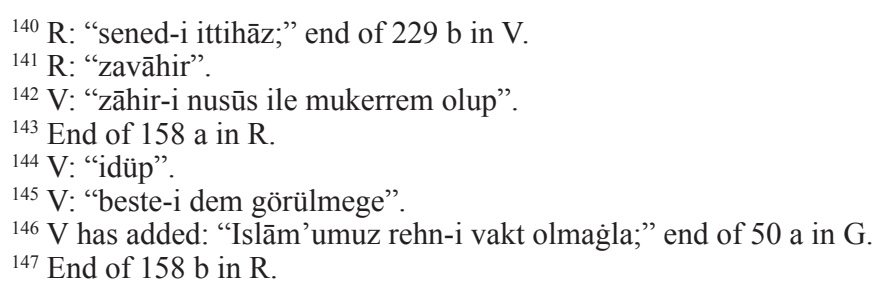


Rūmī' de pnemātīkos ${ }^{148}$ ve lisāni-i Frengī'de konfesar dirler. Bu bendei şūrīde-dil'in dahi hātır-dāşti egerçe hātıra-i ha'ile-i İslām olup havf ve hatari muhtemel idi. Ve-līkin mısrā' ${ }^{\top}$ güzeştem ez sir-i hod herçe der dil dāşstem güftem. Ol rāhibün halvetgāhına vardum nusūs-i mezkūreyi ibrāz ve merkūz'ü’t-tab'olan rāz-i derūn-1 ciğersūz ${ }^{149}$ şerhine āgāa zitdüm. Çünki bende bu şūr ve şagb-i tabi'ile derd-i derūnı gördi bir āh-i gülū-sūz ve hāne-güdāz çeküp ${ }^{150}$ ser be-ceyb-i hayret idüp bir zamān ${ }^{151}$ durd1. Ba'adehu çeşm-i hasret ile nigerān olup, ${ }^{152}$ didi ki "Ey ümmet-i 'Īsā'nın derdnāki, eger āyīn-i pederān ile mezheb-i Hırstiyāni murā'ātında rāsih-dem isen ol ki zebān-zede-i te'vīl-i pīşīnegāndur ma'lūmdur, rāh-i tasvībde sābit-kadem ol, ve ger-ne ta'arruz-1 ${ }^{153}$ bend-i habt $u$ halel tevcīh olup tahti'e-i sāz-1 ictihād isen Beyt: müstemi ' $b \bar{a} s ̧$ ü gūş bā men dār. Zāhir bu hurūf u elfāzın ma'ānīi mevzū'ası müte'ayyindir. Ma'nī-i āhar tahammüline ${ }^{154}$ imkān yokdur. Pes bu takdīrce mā-sadak-1 nusūs ma'a kat'i'n-nazar 'ani'l- 'avārız kim idügi ma'lūm ve mansūsdır. Siyānet-i ${ }^{155}$ pederān içün kenef-i te’vīle ilticā olunmuşdur. Egerçe ${ }^{156}$ sūre- ${ }^{157}$ ziyy-i pederī ki muktezā-y1 hamiyyet-i beşerīdir murādın ise fì-hā ve-illā diyār-1 Frenciyye'de perde ber-endaz-i āyīn olup 'alem-efrāz-i dīn-i İslām olmak fedā-yı ser itmege mevkūfdır. Sen bilursin" deyicek ma 'lūmum oldı ki ${ }^{158}$ bu tā'ifei zāllenin cümlesi herze-kerd-i berzah-1 cehālet olup birisi

$60 \mathrm{a}$

hāric-i dā'ire-i tezebzüb ${ }^{159}$ kadem-nihāde olmamışdur. Hemandem dil ve cāna beyt: Der āteş māndī ey nefs-i belākeş ${ }^{160} /$ Müselmān şev

${ }^{148} \mathrm{~V}$ and G: "pneymatikos".

${ }^{149}$ End of $50 \mathrm{~b}$ in $\mathrm{G}$.

${ }^{150}$ The section from "ciğersuz" to "çeküp" is missing in V. G skips to "ve hānegedāz...".

151 "Bir zaman" is only in A.

${ }^{152}$ End of 230 a in V.

${ }^{153}$ R: "ta'rīz-i".

${ }^{154}$ R: "tahmīline".

${ }^{155}$ V: "āyīn-i pederān".

156 R: "eger".

157 R: "sūver".

${ }^{158}$ End of 159 a in R.

${ }^{159} \mathrm{~V}$ : “tezvir'den".

${ }^{160}$ This is based on R; A gives a metrically incorrect first hemistich: "der ateş mande- $\vec{\imath}$ $v$-ìn hest hoş yārīyem deh.” Cf. V: “der ateş mande-ī v-īn hest nāa-hveş". 
müsellem gerd ez ateş ${ }^{161}$ hitābiyle çünki dergāh-1 kuds-penāh-1 ilāhīden gayrı merce' ve multecā kalmaduġ mute'ayyin ve mü[te]beyyin oldı rū bi-dergāh olup beyt: hudā-yā tu'̄ benderā destgīr / büved benderā

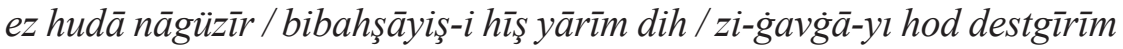
dih / tu-rā hāhem ez her murādī ki hest / ki àyed be-tu her murādī bedest / ne men çāre-i hīş dānem ne kes / tu dānī çünān kün ki dān̄̄ ve bes / safāȳi dih ìn hāk-i tārīkrāa / ki bìnend ez-īn ${ }^{162}$ rāh-i bārīkrāa. Çün bu tazzaru' 1 âhir itdüm bu hitāb-1 gaybi $\overline{1}^{163}$ gūş-zed-i hūş-1 revānim olup kit'a: ey ki pey-i hirs u hevā mīrevī / rāh ne inest kücā mīrevī / rāhrevān z-ān sū-i dīger şüdend / pes tü der ìn rāh hatā mìrevī. Hemāndem cānib-i İslām'a 'atf-i 'inān-1 'azīmet itdüm ve çāyiren ve bāyiren tayyi merāhil idüp merkez-i dāire-i kutb-i İslām olan dārü'l-hulefa-i Kostantiniyye'ye dāhil oldum ve merhūm Sultān Ahmed Hān 'aleyhi'r-rahmetü ve'l-gufrān hvācesi vāsitasiyle dāhil-i meclis-i sultānī oldum, ya'ni merhūm ve magfūr Sultān Ahmed Hān hazretlerinin manzūr-i nazr-i husrevānīsi olup meclis-i şerīflerinde telakkun-i İslām olup ta'yīn-i pādişāhī ile ismimiz Mehemmed olduktan sonra libās-i ruhbānīyi hil'at-i fāhire-i sultanīye tebdīl ve gīsū-yı mesīhīmiz terāşidei tīg-i Ahmed $\overline{1}^{164}$ olup çirāg-i efrūhte-i nūr-i dīnleri ve bende-i dergāh1 devlet-endūhteleri oldum. Nihāyetü'l-emr zebān-1 Türkī tahrīrine ${ }^{165}$ iktidārım yogiidi ki aksa'l-minā olan köşe-i harem-i saltanatlarında inzivā ile ta'allüm-i Kur'ān ve 'ibādet-i İslām'a iştigāl ${ }^{166}$ idem, ba'dehu hālime münāsib en'ām ile muġtenim olam. ${ }^{167}$ Harrartuh bi'l-ibrām fi şehri's-siyām min şuhūri sene hams ve selāsīn ve elf ve ena'l-fakīr Mahmūd bin Hasan al-kādī mü'ellifuh.

${ }^{161} \mathrm{~V}$ : "müsülmān şod müsellem kerd āteş".

162 R: "ki binend īn".

163 This is based on R; A has only "hitāb".

164 R: "Ahmed hāni".

${ }^{165}$ V, R: "tahrīkine".

166 V: "iştifām itdüm".

${ }^{167}$ End of 230 b in V: “temmetü'l-kitāb bi 'avn allāh al-melik al-vehhāb sene selāse ve "işrīn," which most likely refers to 1123/1711-12). End of 51 a in G is not dated. End of 159 b in R: "Harrartuh bi'l-ibrām fī şehri as-sıyām min şuhūr sene erba' ve salāsīn ve elf min al-hicretü'l-nebeviyye 'aleyhu efzāl at-tahiyye v ena'l-fakīr Mahmūd bin Hasan al-kād̄̄ mü'ellifuh". 


\section{Translation}

$57 \mathrm{~b}$

This is a curious treatise by a learned Christian who, having been honored by the glory of Islam, collected the verses from the Gospel and the Torah and the Psalms about the holy mission of prophethood and translated them

This true-believing slave's [i.e. worshipper of God] place of birth is the city of Athens, the source of the philosophical sciences. The established practices that were observed by the ancient Greeks being the currency accepted by the Christian monks, this insignificant slave's undistinguished character was decorated with the ornament of the Christian religion. I was endowed with the marriage-gift of the Christians, and the foot of my conscience and religiosity was shackled to the Christian community so that movement elsewhere was impossible. Because of my monastic promise, from the earliest effort of my childhood to the peak of the bright days of maturity I expended the coin of my refined ambition on acquiring the Christian sciences and turned the reins of gaining credit towards perfecting the Greek sciences.

In the ancient writings of the olden times and among verses difficult to fathom of the patriarchal philosophers ${ }^{168} \mathrm{I}$ became aware of many wondrous words and parables full of strange clues admonitions. Having engaged in extensive discussions with the celebrated monks of the country and the bishops clothed in the mantle of prohibition, I was favored with robes of honor and distinction. Praise be to God Who is the commander of the ordinances of destiny, and Who graciously bestowed divine guidance in the realm of creation and natural religion by furnishing the neck of my body, to which safety was promised, with the collar of acceptance of Islam. With the motto of "God guides whom He will" he urged me to study the celestial books and scriptures containing the ordinances of religion and righteousness and the deeds of the sacred law that must be followed. With this consideration in mind I gradually increased my occupation and study. In the Torah and Psalms and Gospel - upon which all the Jews and Christians agree and which circulate among the Franks (Western Christians) in Latin and among the Eastern

\footnotetext{
${ }^{168}$ Since A here has the word batak meaning "false," this phrase could also mean "false philosophers".
}

Al-Qantara XXXVI 2, 2015, pp. 341-401 ISSN 0211-3589 doi: 10.3989/alqantara.2015.010 
Christians in Greek - I turned my attention to the many doubt-resolving verses and authentic narratives that express the truth of the prophecy of that pearl of the sea of existence, the spiritual teacher of the lovers of God, that brightly shining moon, Muhammad Mustafa (peace be upon him) and confirm the eternity of his religion and sacred law.

58 a

I woke up from the heavy sleep of the darkness of ignorance and sobered up from the drunkenness of the wine of error.

This prologue was necessary before discussing those verses. Now I will expand on the topic. They [verses] are of two types: exoteric, inspired by the tongue of angels and given by command of the King these are also referred to as thoughts inspired by the King (hätır-i melik). ${ }^{169}$ These two types of exoteric verses are not acknowledged by the various infidels who only assent to the type that becomes manifest to the heart of the prophet, decisive in its eloquence, by divine inspiration, and who are also inclined to the esoteric verses that issue from independent judgment of the prophet. Unless an angel mediates the affair relating to the person of the prophet himself, just as Gabriel (peace be upon him) revealed [lit. descended] to Zechariah (the purest greetings be upon him) the good news of the birth of a virtuous child, as mentioned in the Torah: "The horse and its rider he has hurled into the sea." ${ }^{170}$ This verse is one the pearls of the Mosaic scriptures threaded on the lines of the Torah. Job (peace be upon him), who unfurled the banner of patience and honor while he was the custodian of the treasury of prophecy, took these priceless pearls and bequeathed them as guidance to the community. And when Moses (peace be upon him) held the staff of prophecy he related them to the community as issuing from his prophetic manifesto. The meaning of this verse is that our life that is passing with our errors and crimes resembles a helpless person in a violent winter storm flung into the roiling sea with a shore nowhere in sight who is certain to drown without a boat and boatman to rescue him. We too need the boat of the sacred law and the boatman who knows the sea of truth in order to save us from the dangerous sea of error and from the perilous abyss of sin.

${ }^{169}$ Equivalent of "hātır-1 rabbān̄̄" ("A thought inspired by God").

${ }^{170}$ Exodus 15:1. I thank Prof. Robert Dankoff for identifying this verse. 
The spiritual leaders of the Christians and Jews understand Noah's ark (peace be upon him) exoterically as the exemplar of truth. I too, having drawn the pearls of meaning of these words of wisdom on the string of understanding and acceptance, the water of guidance having been sprinkled on the face of drowsiness, awoke from the sleep of neglect. Realizing that it was my duty to search out the boat and the boatman, I became a diver in the sea of investigation. Giving the steed of my nature free rein in order to study the whole contents of the Torah I found in another place the following passage: "The sceptre shall not depart from Judah, nor a lawgiver from between his feet, until Shiloh come; and unto him shall the gathering of the people be." 171 This passage is also in the pages of the Torah from the pen of Moses (peace be upon him). It is the headband of the verses comprising the testament of Jacob (peace be upon him) to his noble sons, drawing on the pages of their minds and delegating the duty of remembrance. And Moses (peace be upon him) as well, during his wisdom-scattering prophetic mission, by divine inspiration heralded to his community the glorious arrival of the lord of the world [i.e., the Prophet Muhammad]. The meaning of this passage is that Jacob addresses his noble sons and says: "Oh my sons, the line of prophecy and political dominion will not be cut off from you until he arrives. After he arrives, they will be cut off. The whole world is awaiting his coming."

The Christian teachers of the Torah claim falsely that Jacob

$58 \mathrm{~b}$

is referring to the promised arrival of Jesus. But the divers in the sea of meanings interpret this pearl [i.e. eloquent saying] to mean that when Jacob says, "When he arrives, the line of prophecy and political dominion will be cut off from you," this is a link in the necklace of the truly-ordered words, so their assertions are rendered void by admission of magic [or being under a spell [?]] and they become tongue-tied. Because in the time of Jesus's prophethood the Israelite leaders were still picking crumbs at the table of political power and the ornamental singing green-beaked parrot was still feeding on the sugar of government. And so the decisive bond of his prophetic mission was a falcon

${ }^{171}$ Genesis 49:10. 
fettered to that era. ${ }^{172}$ Obviously, therefore, the cutting off of prophecy and political dominion could not occur [at that time].

The obstinate Jews as well, wandering in the wilderness of error, when they interpret this passage [1it. when they make a fair copy of this rough draft] make the false claim that Muhammad (peace be upon him) was sent only to his own people and that the owner of the divine right to rule whose arrival is awaited by everyone has not yet placed his foot into the visible world, and that the universal expectation remains unchanged. But the interpretation of the speakers of truth regarding this claim is that when the necklace of the reign of the Israelites is removed from their neck and the young sapling of the Ishmailites is planted in the garden of prophecy, according to the sense of what was recorded above, it is obvious that the thread of prophecy and political dominion will certainly be cut off from the Israelites and the truth of the prophecy of Muhammad will necessarily appear. Their futile expectation testifies to their great denial of truth and to the corruption of their deeds.

Verse: Their purpose was nothing but disgrace. / How could Christians or Jews seek the goodness of religion? ${ }^{173}$

Then the meaning of this passage took wondrous forms in my imagination and the truth of Muhammad's prophecy excited me more and more and caused me to increase my studies. With the divine urging I also found this passage in the Torah: "A prophet shall the Lord your God raise up unto you of your brethren, like unto me... And it shall come to pass, that every soul, which will not hear that prophet, shall be destroyed from among the people." ${ }^{174}$ This verse that adorns the meadows of the pages of the Torah is the one in which Moses (peace

\footnotetext{
${ }^{172}$ This idea of the falcon as image of the prophet comes out of Rumi's Mathnawī. On this issue see Renard, All the King's Falcons. Rumi on Prophets and Revelation. I thank Gottfried Hagen for this reference.

${ }^{173}$ Nicholson, The Mathnawi of Jalálu'ddín Rúmí, vol. II, v. 2860. I thank Ferenc Csirkés for this reference.

${ }^{174}$ Acts 3:22-23. What the author has in mind when he says that he is citing from the Torah is likely the analogous passage from Deuteronomy 18: 18-19: "I will raise them up a Prophet from among their brethren, like unto thee, and will put my words in his mouth; and he shall speak unto them all that I shall command him. And it shall come to pass, that whosoever will not hearken unto my words which he shall speak in my name, I will require it of him" (accessible at: http://www.biblegateway.com/passage/? search=Deuteronomy+18\&version=KJV [accessed on April 30, 2013]).
} 
be upon him) declares to the Israelites: "God has commanded that from among your brothers He will send a prophet like me and that He will destroy and seek vengeance upon everyone who opposes His command." Interpreting the claims of the Torah, the straying Christians, who also lay claim to the Torah, make the false claim that this promised messenger is the glorious Jesus (peace be upon him). But those strict critics who minutely examined this passage have established that the promised messenger of high rank "from among your brothers" featuring in the miraculously ordered words of Moses will not be of the Israelite lineage but must come from the branch of a tree of a different garden; and the words "like me" signify that like himself [Moses, and unlike Jesus] he will be born of a father and a mother. And the verse saying that "He will destroy whoever opposes his command" implies that the established rituals will be abolished and the wicked threat of opposition will be extirpated. Clearly, therefore, it is not Jesus [that Moses referred to] and their assertion is manifestly false.

Afterwards the mind-consuming love of Muhammad made my heart agitated and stirred my thoughts:

Verse: Passion for you enters our head. / Look what things there are rolling in a perplexed head!

An internal struggle with the deceitful heart of madness in the ambush of investigation incited a strong desire to study the Psalms of David. There I found this doubt-resolving passage: "In his days shall the righteous flourish; and abundance of peace so long as the moon endureth. He shall have dominion also from sea to sea, and from the river unto the ends of the earth. They that dwell in the wilderness shall bow before him; and his enemies shall lick the dust...

59 a

Yea, all kings shall fall down before him." 175 In other words, God says to David (peace be upon him): "After you I shall send a prophet bearing a sacred law the lights of whose seal of prophecy will scatter rays to the east and west. The first of his community who will follow him will be of the Arab people. Those obstinate ones who oppose him will be overcome and abased. The rulers of the world will make his law a collar on the neck of obedience. His religion and law will last until the Day

${ }^{175}$ Psalms 72: 6-10. 
of Judgment." As before, the band of opponents engages in nonsensical interpretation and once again say that it refers to Jesus. Since the reply to them is very apparent, there is no need to go into particulars.

Let it be known that the writers of the Gospels were four of the apostles who were falcons fettered by unbreakable bonds to the company of Jesus (peace be upon him) and whose inspired words they registered in the pages of the Gospels. Consequently the Gospels consist of four parts known after their authors as the Gospels of John, Matthew, Luke and Mark. The Gospel of John contains the verbal description of Muhammad, but since deviant Christians followed an interpretation of these words that was unacceptable, they fell into the pit of rebellion and were unable to save their necks from the deception of rebellion.

The Gospel of Matthew as well contains the following passage which cuts the veins of opponents and eloquently attests to the necessity of the glorious arrival of Muhammad, lord of the world (peace and great honor be upon him): "He that cometh after me is preferred before me: for he was before me ... the latchet of whose shoes I am not worthy to unloose." 176 The meaning is that Jesus says: "The one who will come after, who was created before me, I am not worthy to untie the strap of his sandal." It is well known that in explaining these passages, the nonsensical Christians and the envious Jews make claims that identify the bearer of the prophetic mission spoken of in these verses either [for the Christians] as Jesus or [for the Jews] as the awaited Messiah, citing numerous untenable premises to support their deficient opinions. Now when Jesus brought forth the platter of speech from the gem shop of holiness he strung this pearl of truth on the cord of eloquence and defeated the band of opponents with the tumult of "Now the truth is out." 177 They were like so many dogs who swallowed pins and with wounded throats no longer able to scream could only persist in denial and infidelity. Advocating their claims in this way, they say that these devotion-causing words about the acceptance of servitude and bonds of submission that are implied in the untying of the strap of the sandal were uttered by John [the Baptist] about Jesus. However, it

${ }^{176}$ This quotation is actually a mix of John $1: 15$ and Luke 3:16, rather than of a verse from Matthew (3:11). I am grateful to Professor István Ormos for helping me resolve the confusion over the author's mixed citations.

${ }^{177}$ Qur'ān 12:51 (The Meaning of the Glorious Qur'ân, Mohammad M. Pickthall, Hyderabad-Deccan, Government Central Press, 1938, accessible at: http://www.sacredtexts.com/isl/pick/012.htm [accessed on June 30, 2013]). 
is not concealed from those who wear [lit. cover themselves] with the cloak of veracity and justice that the apostles' stream of belief was free from the rubbish of polytheism and obstinacy. The above-mentioned passage, being the words of Jesus, was recorded in the pages of the Gospel and has circulated among them from that time until now. So it is obvious that their recourse to such nonsensical interpretation is simply the lack of anything to lean on.

Verse: The pain I had became a hundred-fold stronger. / The confusion I was in went beyond the limit.

My affliction of suffering made these collected passages the repeated litany of the tongue of my soul. The more I examined them the more I saw that their virgin meanings, taking shape in my imagination, were all betrothed to the prophethood of Muhammad (prayers and peace be upon him) and their implications that emerged from the nuptial chamber of these lines as if seated on the bridal throne embraced the prophetic neck of Muhammad. As the jewels of their secrets that comprised their hidden words were pierced with the attributes of Muhammad Mustafa, gradually my certainty increased and the witness of the love of Islam began to appear in the polished mirror of my nature. But not having the courage to abandon completely the old established rituals, to untie the girdle of unbelief

$59 \mathrm{~b}$

and to be completely illumined by the light of Islam, I had recourse in the resolution of this matter to consultation with famous monks of the lands of Rum.

Verses: When the sage faces a problem / that hinders him in his dealings / he adds another wise mind to his own / to have help in solving it. / As his house cannot be lit by a single candle / he puts another candle in the middle. ${ }^{178}$

Although the bearer of evil cannot be the guide to good, there was a possibility that in the course of discussion the truth would emerge. If they could realize that the interpretation they held was nonsensical, it

178 Jāmī, "Yūsuf va Zalīkhā", p. 636. These are the first two lines of the part where Joseph's brothers are debating how to distance him from his father. I thank Ferenc Csirkés for identifying this verse and translating it into English. All subsequent Persian verses have also been identified and translated into English by him. 
would facilitate proving their vain denials. With this in mind, I embarked on a journey around the lands of Rum. I visited town after town, village after village, and everywhere I met with the priests and monks distinguished and famous for their learning and science. After many discussions and debates I discovered what was in their minds. Some said, "It is difficult to abandon old and familiar customs blessed by our ancestors." Some, silenced by the irrefutable verses [that I brought forth], did not try to refute them but nor did they accept them. And some said: "These doubt-resolving verses incontrovertibly demonstrate the truth about Muhammad's prophetic mission. In the end, tearing the curtain of secrecy depends on divine guidance." All of them were struck by amazement at the hidden secrets and appeared downcast and dumbstruck. This only increased the confusion in my mind and I did not yet dare to remove the curtain of unbelief.

Verse: The rust of sorrow has not left the mirror of my disposition. / Alas, the beloved who reveals his face has not died but he is gone. / The rose of my purpose has not blossomed in the garden of inner meaning. / Despite my efforts the palmtree of the plain of my hopes has not given fruit. / Alas, the white falcon of aspiration soared up / but did not catch the partridge of my heart's desire afflicted by a hundred pains. I In the bridal chamber of renunciation remained concealed with wonder / The virgin meaning of desire and did not present the beloved's face.

While I was in this state of bewilderment it occurred to me that all the learned men from the ranks of the infidels are in great Rome, that is also known as the Red Apple, the place of abode of the Pope who resolves all doubts. So I went there with the purpose of resolving the matter. I resided there for four years and diligently inquired into the thoughts of the erring sects. I was amazed to see all of them wandering in the wilderness of error. One of the current practices of the infidels is that they choose from among themselves a knowledgeable and experienced priest who is advanced in years and appoint him to a certain place. Whoever has doubts, whether religious or worldly, reveals them to him and gets his reply. He in turn does not disclose the questions he is asked, even if the matter is a capital offense; and if he does, he is removed from that office. This priest who can be trusted for advice is called in Greek pneumatikos and in Latin confessor. I well knew that if I brought up the dreaded topic of Islam, that was troubling my mind, it could prove dangerous. Nevertheless,

Verse: I gave up my secret and told everything that was in my heart. 
I went to that priest's place of seclusion, showed him the abovementioned verses, and began to expound the heart-burning secret that was fixed in my nature. When he saw the deep trouble and confusion in me, he heaved a throat-burning and house-melting sigh, drew his head into the shirt-neck of perplexity and stood there for a while. Then gazing at me with the eye of longing he said: "Oh sorrowful one of the community of Jesus! If you remain constant in showing respect to the Christian rite with its ancestral rituals, the interpretation of the ancients, constantly repeated, is well-known. Persevere in the way of approbation. Otherwise, if you turn in the direction of error and follow the siren call of personal interpretation — Listen and give me your ear ${ }^{179}$ - the plain meaning of these letters and words is manifest and there is no possibility of other meanings. Accordingly, it is known and supported by scriptural authority, without regard to defects [in the argument?], who is referred to in these passages. For the preservation of the ancestors, refuge was sought in the margin of interpretation. If your desire is to respect the ancestral cloak, which is required by the human sense of honor, then stay with that. Otherwise, removing the curtain of custom in the lands of the Franks and unfurling the banner of the religion of Islam will condemn you to sacrificing your head. Do what you think is right!"

I realized that all this tribe of error were fomenting nonsense in the purgatory of ignorance. Not one

$60 \mathrm{a}$

stepped outside the circle of confusion. As soon as according to the verse: You have remained in the fire, o suffering soul. / Be a Muslim, become free from the fire! ${ }^{180}$ it became clear no refuge remained for me but the sacred convent of God's protection.

Verse: $O, G o d$, you are the one that helps this slave. / You are indispensable for this slave. / Give me your mercy as company. / Help me out of my own tumult. / Of all my wishes I want You, / for with You every desire is obtained. / Neither I nor anyone else knows a solution, / but You know, so act accordingly, that is enough. I Give purity to this dark earth / so that they can see this narrow road.

${ }^{179}$ Hilālī Chaghatāyī, Shāh u Darvīsh. Cf. Browne, A Literary History of Persia, vol. 4, pp. 234-5.

${ }^{180}$ Niz̄āmī Ganjavī, Khusraw va Shìrīn, p. 497, line 32. This quotation is taken from part 97, which is the Prophet's letter to Khusraw. 
When I had finished this humble prayer, a voice from the unseen world addressed the ear of my soul as follows.

Verse: Oh you who follow cupidity and desire! / This is not the (right) road. Where are you going? / The travelers of the path have gone in another direction. / So you are going the wrong way.

I immediately turned the reins of intention in the direction of Islam. Passing over hill and dale, rolling up the stages of my journey, I arrived at the center of the circle of the pillar of Islam, the seat of the caliphs, Constantinople. Through the intercession of the teacher of the late Sultan Ahmed Han (may God grant him mercy and forgiveness) I entered the imperial council. That is to say, under the watchful imperial gaze of the late Sultan Ahmed Han himself, I received instruction in Islam in the glorious divan and my name became Mehemmed [Muhammad] by the sultan's own designation. After that, I exchanged my priestly garment for the splendid sultanic robe of honor and my Christian locks were shaved by the Ahmedian razor. I became a torch kindled by the light of religion and a slave in the court of the sultanic state. Finally, I did not know how to write Turkish language; my utmost desire was to withdraw into a corner of the imperial harem and occupy myself with learning the Qur'ān and Muslim worship, so that eventually I would become laden with presents appropriate to my status.

I, the writer of this document, the poor Mahmud bin Hasan, the judge, wrote this in the month of Ramadan in the year 1035 .

\section{Bibliography}

Abdesselam, Ahmed, Les historiens tunisiens des XVIIe, XVIIIe et XIXe siècles, Tunis, Klincksieck, 1973.

Abun-Nasr, Jamil M., A History of the Maghrib in the Islamic Period, Cambridge, New York, Cambridge University Press, 1987.

Alvarez, Lourdes Maria, "Anselm Turmeda: The Visionary Humanism of a Muslim Convert and Catalan Prophet," in Albrecht Classen (ed.), Meeting the Foreign in the Middle Ages, New York, London, Routledge, 2002, pp. 172-191.

Atâî, Nev'îzâde, Hadayiku'l-hakaik fi tekmileti'ş-şakaik, A. Özcan (ed.), İstanbul, Çağrı Yayınları, 1989.

Baer, Marc, Honored by the Glory of Islam: Conversion and Conquest in Ottoman Europe, New York, Oxford University Press, 2008. 
Benafri, Chakib, 'Endülüs’te son Müslüman kalıntısı Morisko'larin Cezayir'e Göçü ve Osmanlı Yardımı (1492-1614)," unpublished M. A. thesis, Hacettepe Üniversitesi, Ankara, 1989.

Bernabé Pons, Luis F., "Notas sobre la cohesión de la comunidad morisca más allá de su expulsión de España," Al-Qanțara 29, 2 (2008), pp. 307-332.

Bernabé Pons, Luis, El evangelio de San Bernabé: un evangelio islámico español, Alicante, Universidad de Alicante, 1995.

Boase, Roger, "Autobiography of a Muslim Convert: Anselm Turmeda (c. 1353c. 1430)," Al-Masaq 9 (1996-97), pp. 45-98.

Börekci, Günhan, "Factions and Favorites at the Court of Sultan Ahmed I (r. 16031617) and His Immediate Predecessors," unpublished PhD Thesis, The Ohio State University, 2010.

Boubaker, Sadok, "Activités économiques des morisques et conjuncture dans la régence de Tunis au XVIIe siècle" (available at: http://www.moriscostunez. com/2010/01/activites-economiques-des-morisques-et.html, [accessed $10 / 06 / 2013])$

Browne, Edward G., A Literary History of Persia, Cambridge, Cambridge University Press, 1959.

Burak, Guy, "Faith, Law, and Empire in the Ottoman 'Age of Confessionalization' (Fifteenth-Seventeenth Centuries): the Case of 'Renewal of Faith'," Mediterranean Historical Review 28/1 (2013), pp. 1-23.

Coşan, M. Esad, Risâle-i Islâmiyye. Matbaacı İbrahim-i Müteferrika ve Risâle-i Islâmiyye Adlı Eserinin Tenkitli Metni, Necdet Y1lmaz (ed.), $2^{\text {nd }}$ ed., Server İletişim: İstanbul, 2010.

Epalza, Míkel de, "Arabismos en el manuscrito castellano del Morisco tunecino Ahmad al-Hanafî," Homenaje a Álvaro Galmés de Fuentes, vol. II, MadridOviedo, Gredos-Universidad de Oviedo, 1985, pp. 515-27.

Epalza, Míkel de, Fray Anselm Turmeda ('Abdallāh al-Taryumān) y su polémica islamo-cristiana. Edición, traducción y estudio de la Tuhfa, 2nd ed., Madrid: Hiperión, 1994.

Epalza, Míkel de, "Moriscos y andalusíes en Túnez durante el siglo XVII," AlAndalus 34, 2 (1969), pp. 247-327.

Epalza, Míkel de, “Nota sobre un nuevo 'falso' en árabe, de moriscos en el exilio, antes de la expulsión general (Túnez 1603?): la pseudo-Tuhfa de Turmeda (3a parte)," Sharq al-Andalus 18 (2003-2007), pp. 133-44.

Epalza, Míkel de, "Sidi Bulgayz, protector de los Moriscos exiliados en Túnez, (s. XVII)," Sharq al-Andalus 16-17 (1999-2002), pp. 141-172.

Fierro, Maribel, "El Tahd $\underline{\bar{\imath}} b$ de al-Barādi ${ }^{‘} \overline{1}$ en al-Andalus: a propósito de un manuscrito aljamiado de la Real Academia de la Historia," al-Qanțara 21/1 (2000), pp. 227-36.

García-Arenal, Mercedes, "Dreams and Reason: Autobiographies of Converts in Religious Polemics," in Mercedes García-Arenal (ed.), Conversions is- 
lamiques: identités religieuses en Islam méditerranéen, Paris, Maisonneuve et Larose, 2002, pp. 89-118.

Griffith, Sidney H., "The Gospel in Arabic: An Inquiry into its Appearance in the First Abbasid Century," Oriens Christianus 69 (1985), pp. 126-167.

Hagen, Gottfried, "Katib Çelebi," in C. Kafadar, H. Karateke, and C. Fleischer (eds.), Historians of the Ottoman Empire (accessible at http://ottomanhistorians.uchicago.edu/en/historian/katib-celebi [accessed on 15/06/2014])

al-Hajarī, Aḥmad ibn Qāsim, Kitāb nāșir al-dīn 'alā'l-qawm al-kāfirīn (The Supporter of Religion Against the Infidels), P. S. Van Koningsveld, Q. al-Samarrai, G. A. Wiegers (eds. and trans.), CSIC: Madrid, 1997.

Jāmī, 'Abd al-Raḥmān, "Yūsuf va Zalīkhā” in Murtazḍā Mudarris Gīlānī (ed.), Masnavī-yi Haft awrang, Tehran, Kitābfurūshī-yi Sa'dī, 1337 [1958].

Kâtip Çelebi, Keşfü'z-zunûn an esâmi'l-kütübi ve'l fünûn, Rüştü Balci (trans.), Istambul, Tarih Vakfı Yurt Yayınları, 2012 (2007), 5 vols.

Khuja, Husayn, Dhayl bashā 'ir ahl al-īmān bì futūḥāt āl 'Uthmān, al-Ṭāhir alMa'mūrī (ed.), Tunis, Maison Arabe du Livre, 1395/1975.

Krstić, Tijana, Contested Conversions to Islam: Narratives of Religious Change in the Early Modern Ottoman Empire, Palo Alto, Stanford University Press, 2011.

Krstić, Tijana, "Contesting Subjecthood and Sovereignty in Ottoman Galata in the Age of Confessionalization: The Carazo Afair, 1613-1617," Oriente Moderno 93 (2013), pp. 422-453.

Krstić, Tijana, "Illuminated by the Light of Islam and the Glory of the Ottoman Sultanate: Self-Narratives of Conversion to Islam in the Age of Confessionalization," Comparative Studies in Society and History 51/1 (2009), pp. 54-58.

Le Strange, Guy (ed.), Don Juan of Persia: A Shi 'ah Catholic, 1560-1604, New York and London, Harper and Brothers, 1926.

Levi Della Vida, Giorgio, "Manoscritti Arabi di Origine Spagnola nella Biblioteca Vaticana," Studi e Testi 219-220 (1962), pp. 133-189.

Lotz-Heumann, Ute, "The Concept of "Confessionalization.” A Historiographical Paradigm in Dispute," Memoria y Civilización 4 (2001), pp. 93-114.

Mazur, Peter and Shinn, Abigail, "Introduction: Conversion Narratives in the Early Modern World," Journal of Early Modern History 17 (2013), pp. 427-436.

Nicholson, Reynold A. (ed. and trans.), The Mathnawi of Jalálu'ddin Rúmí, London, Trustees of the "E. J. W. Gibb memorial," 1925-1940.

Niẓāmī Ganjavī, Khusraw va Shīrīn, (ed.) Bihrūz Sarvatiyān, Tehran, Mu’assasayi Intishārāt-i Amīr Kabīr, 1386 [2007/8].

Paker, Saliha, "Translation, the Pursuit of Inventiveness and Ottoman Poetics: A Systemic Approach," in R. Sela-Sheffy and G. Toury (eds.), Culture Contacts and the Making of Cultures, Tel Aviv, 2011, pp. 459-74.

Pieri, Henri, “L'accueil par des Tunisiens aux Morisques expulsés d'Espagne: un témoignage morisque," in Míkel de Epalza and Ramon Petit (eds.), Recueil 
d'études sur les Moriscos andalous en Tunisie, Madrid, Instituto hispanoárabe de Cultura, 1973, pp. 128-134.

Pfeiffer, Judith, "Confessional Polarization in the $17^{\text {th }}$-Century Ottoman Empire and Yusuf Ibn Ebi 'Abdü'd-Deyyan's Keşfü'l-esrār fì ilzāmi'l-Yehūd ve'lahbār," in C. Adang and S. Schmidtke (eds.), Contacts and Controversies between Muslims, Jews and Christians in the Ottoman Empire and Pre-Modern Iran, Würzburg: Ergon Verlag, 2010, pp. 15-56.

Podskalsky, Gerhard, Griechische Theologie in der Zeit der Türkenschaft (14811821), Munich, C. H. Beck Verlag, 1987.

Rank, Scott, "Disputting Religion, Empire and Modernity: Christian-Muslim Polemics in the Ottoman Print Sphere, 1861-1915," PhD Thesis, Department of History, Central European University, 2015.

Renard, John, All the King's Falcons. Rumi on Prophets and Revelation, New York, State University of New York Press, 1994.

Reynolds, Dwight F. (ed.), Interpreting the Self: Autobiography in the Arabic Literary Tradition, Berkeley and London: University of California Press, 2001, pp. 194-201.

Runciman, Steven, The Great Church in Captivity, Cambridge, Cambridge University Press, 1968.

Schmidt, Jan, "An Ostrich Egg for Golius; the John Rylands Library MS Persian 913 and the History of Early Modern Contacts between the Dutch Republic and the Islamic World" in Jan Schmidt, The Joys of Philology, vol. II, Istanbul, Isis Press, 2002, pp. 9-74.

Schmidt, Jan, Catalogue of Turkish Manuscripts in the Library of Leiden University and Other Collections in the Netherlands, 3 vols., Leiden, 2000-2006.

Schmidtke, Sabine and Adang, Camilla, “Aḥmad b. Muṣṭafā Ṭashkubrīzāde’s (d. 968/1561) Polemical Tract Against Judaism," Al-Qantara 29/1 (2008), pp. $79-113$.

Spiro, Jean, Le present de l'homme lettré pour refuter les partisans de la croix, Paris, E. Leroux, 1886.

Szpiech, Ryan, Conversion and Narrative. Reading and Religious Authority in Medieval Polemic, Philadelphia, University of Pennsylvania Press, 2013.

Szpiech, Ryan, "The Original is Unfaithful to the Translation: Conversion and Authenticity in Abner of Burgos and Anselm Turmeda," eHumanista 14 (2010): pp. 146-77 (available at: http://www.ehumanista.ucsb.edu/volumes/ volume_14/Arabic/Szpiech.pdf, [accessed on 17/06/2-13]).

Strauss, Johann, “Müdafaa'ya Mukabele et Mukabele'ye Müdafaa: une controverse islamo-chrétienne dans la presse d'Istanbul (1883)," in C. Herzog, R. Motika and M. Ursinus (eds.), Querelles privées et contestations publiques. Le rôle de la presse dans la formation de l'opinion publique au Proche Orient, Isis: Istanbul, 2002, pp. 55-98.

Temimi, Abdeljelil, “Évolution de l'attitude des autorités de la Régence de Tunis 
face à l'acceuil des Morisques, à la lumière d'un nouveau firman du sultan ottoman," Revue d'histoire maghrébine 69-70 (1993), pp. 169-180.

Temimi, Abdeljelil, Le Gouvernement Ottoman et le Problème Morisque, Zaghouan, Centre d'etudes et de recherches ottomanes, morisques, de documentation et d'information, 1989.

Temimi, Abdeljelil, "Politique ottomane face à l'expulsion des Morisques et à leur passage en France et Venice 1609-10," Revue d'histoire maghrébine 7980 (1995), pp. 397-420.

Temimi, Abdeljelil, "Politique Ottomane face à l'implantation et à l'insertion des Morisques en Anatolie," in Míkel de Epalza (ed.), L'expulsió dels moriscos, Barcelona, Generalitat de Catalunya, 1994, pp. 164-170.

Terzioğlu, Derin, "How to Conceptualize Ottoman Sunnitization: A Historiographical Discussion," Turcica 44 (2012-13), pp. 301-38.

Terzioğlu, Derin, "Where Illm-i hal Meets Catechism: Islamic Manuals of Religious Instruction in the Ottoman Empire in the Age of Confessionalization," Past \& Present 220 (August 2013), pp. 79-114.

Tezcan, Baki, “İbrâhîm Müteferrika ve Risâle-i Íslâmiyye," in Hatice Aynur, Bilgin Aydın, Mustafa Birol Ülker (eds.), Kitaplara Vakfedilen Bir Ömre Tuhfe: İsmail E. Erünsal'a Armağan, Vol. 1, İstanbul: Ülke Yayınları, 2014, pp. 515 556.

Tezcan, Baki, The Second Ottoman Empire. Political and Social Transformation in the Early Modern World, Cambridge, New York, Cambridge University Press, 2010.

Tornberg, Carl Johan, Codices Arabici, Persici et Turcici Bibliothecae Regiae Universitatis Upsaliensis, Uppsala, Universitas Upsaliensis, 1849.

Turki, Abdelmajid, "Documents sur le dernier exode des Andalous vers la Tunisie," in Míkel de Epalza and Ramon Petit (eds.), Recueil d'études sur les Moriscos andalous en Tunisie, Madrid, Instituto hispano-árabe de Cultura, 1973, pp. 114-127.

Wiegers, Gerard A., "European Converts to Islam in the Maghrib and the Polemical Writings of the Moriscos," in Mercedes García-Arenal (ed.), Conversions islamiques: identités religieuses en Islam méditerranéen, Paris, Maisonneuve et Larose, 2002, pp. 207-223.

Recibido: $27 / 06 / 2013$

Aceptado: 16/12/2014 


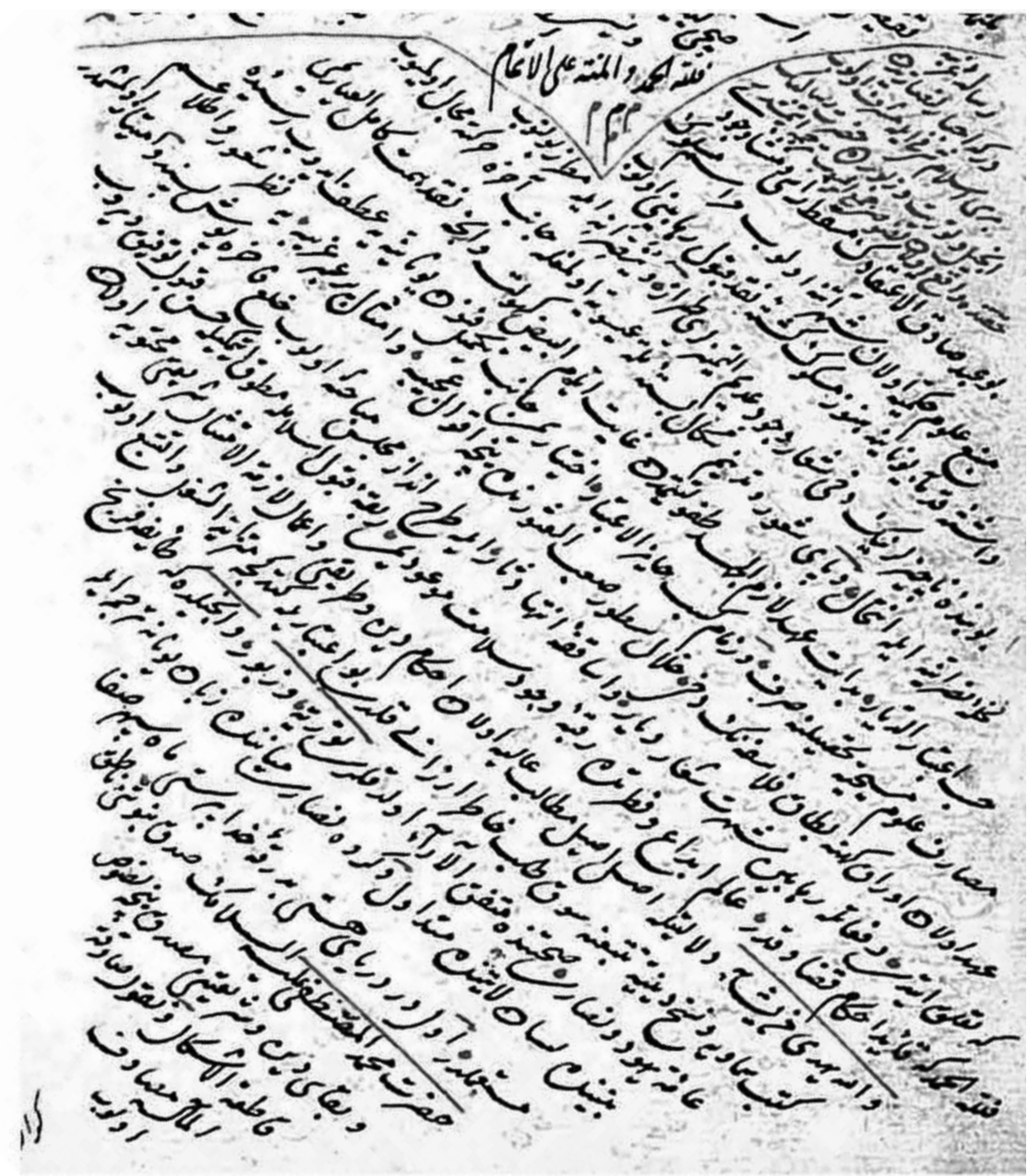

Ali Ninat Tarlan 57b 


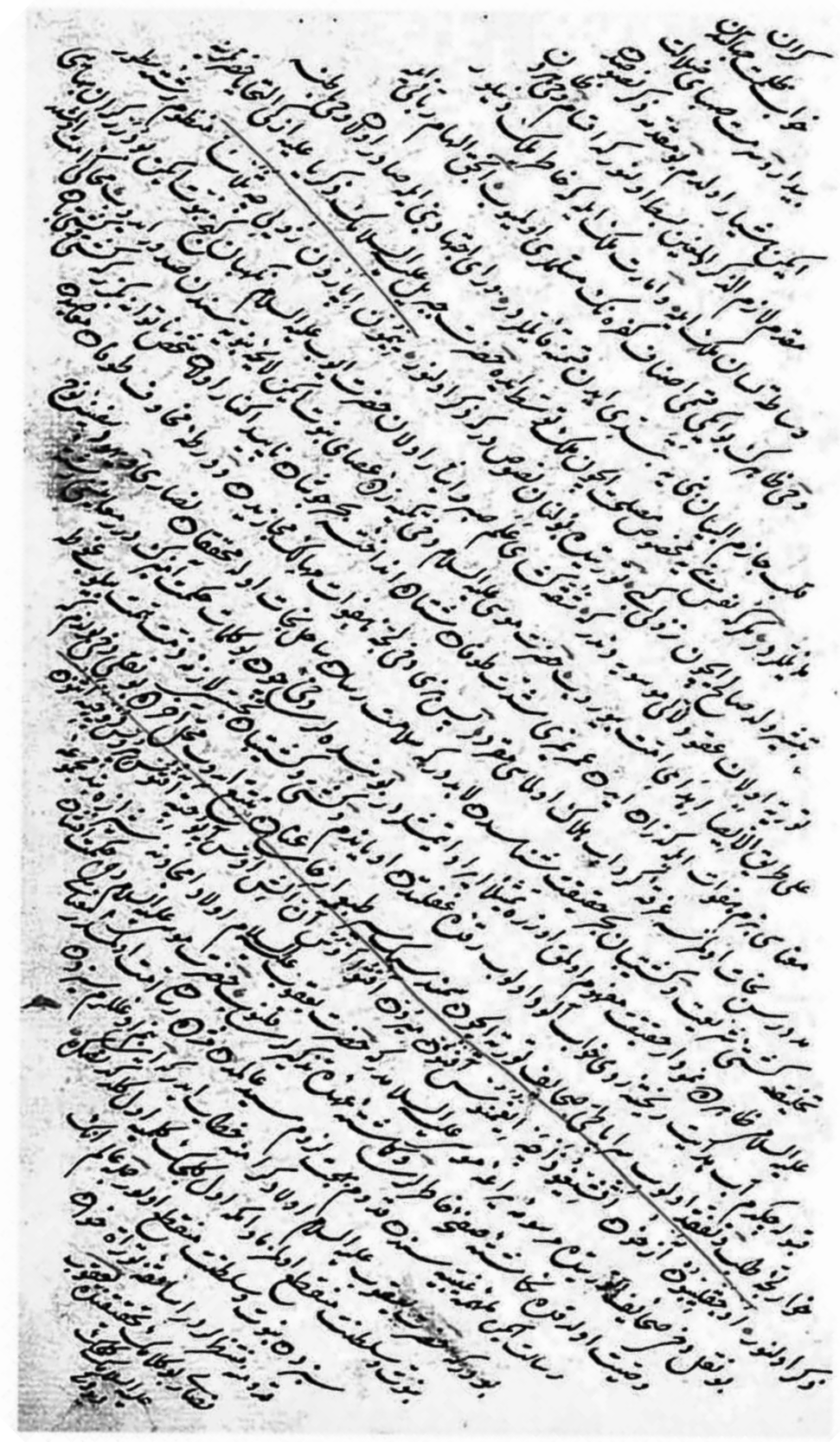

Ali Ninat Tarlan 58a 


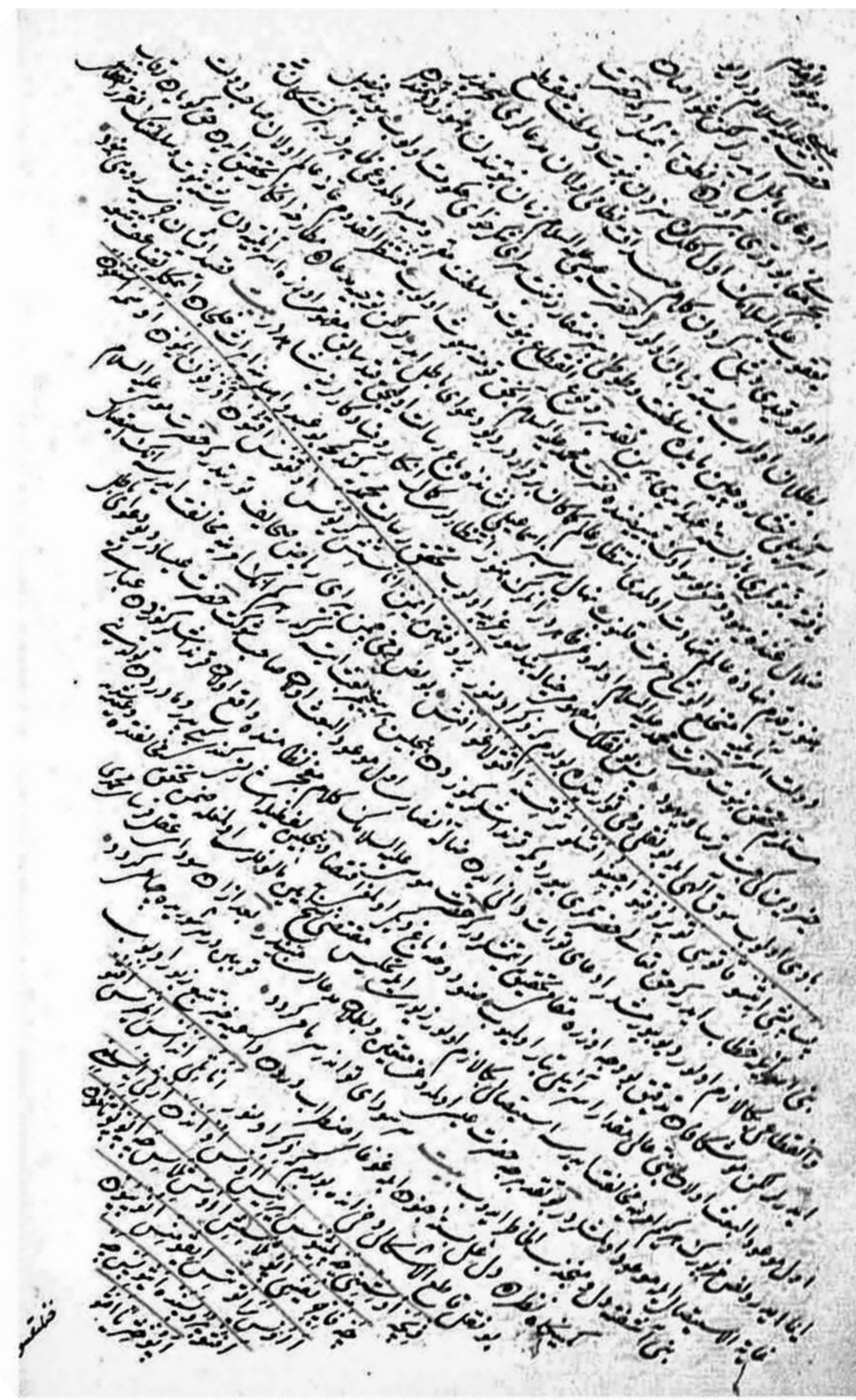

Ali Ninat Tarlan 58b 


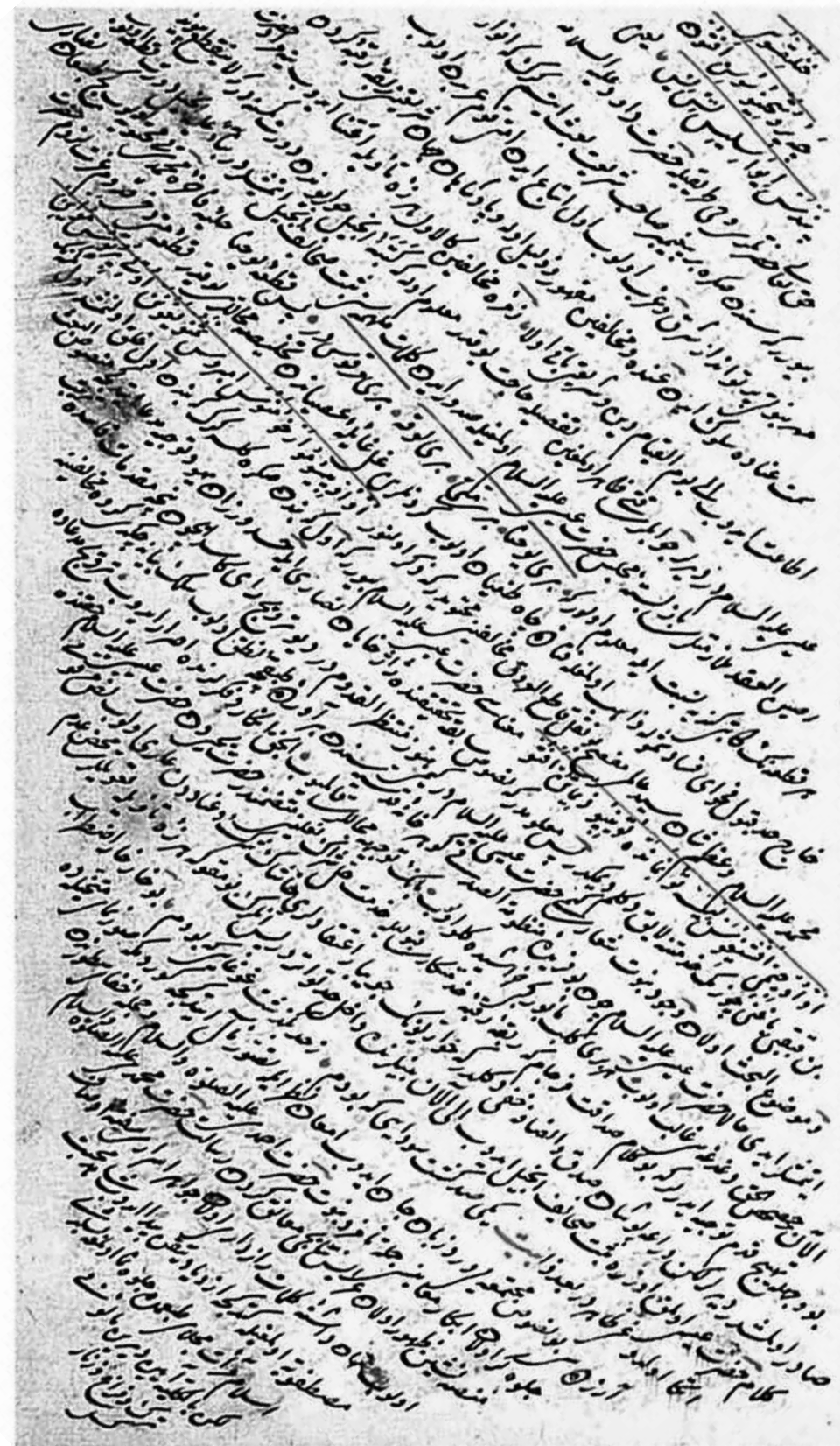

Ali Ninat Tarlan 59a 


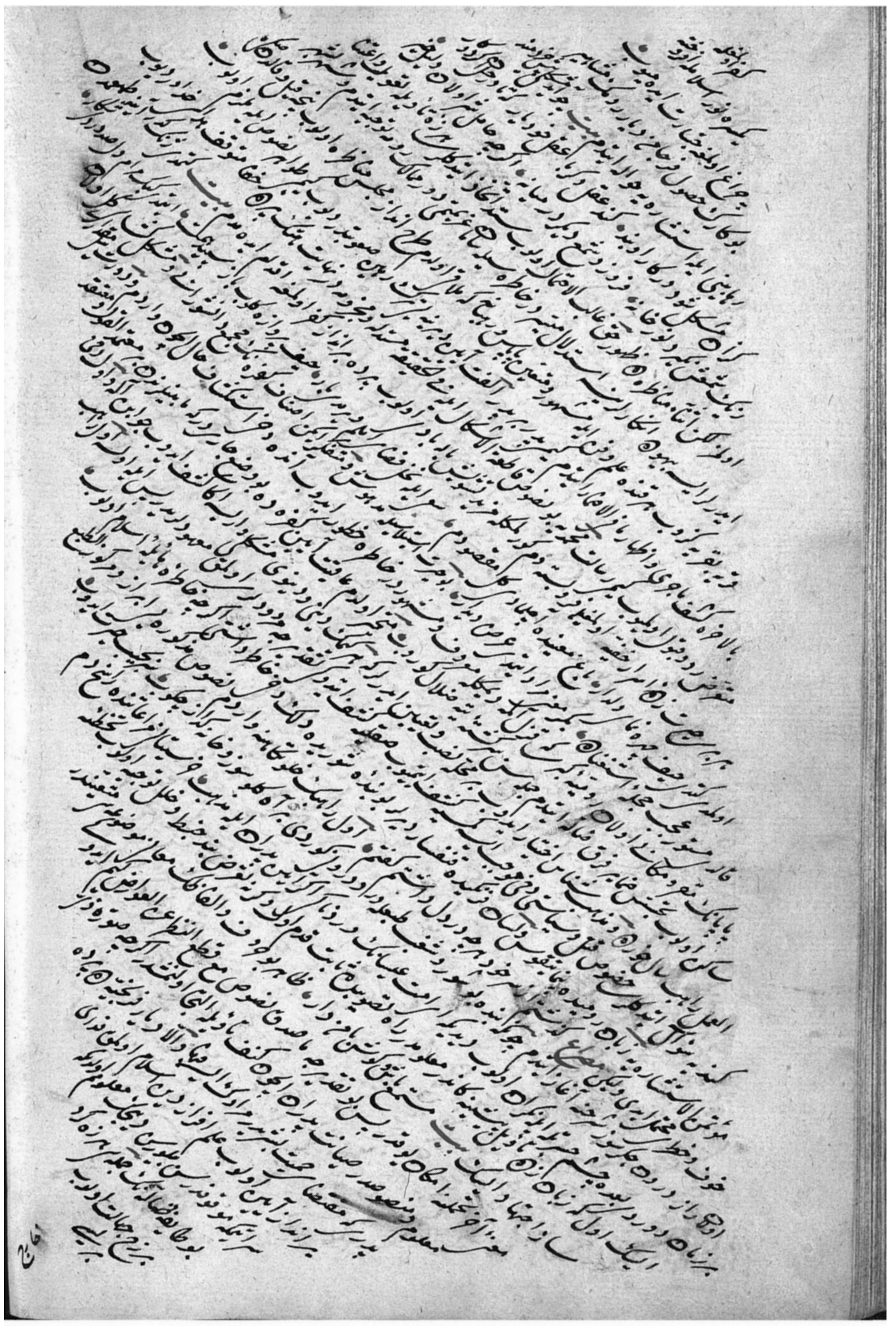

Ali Ninat Tarlan 59b 


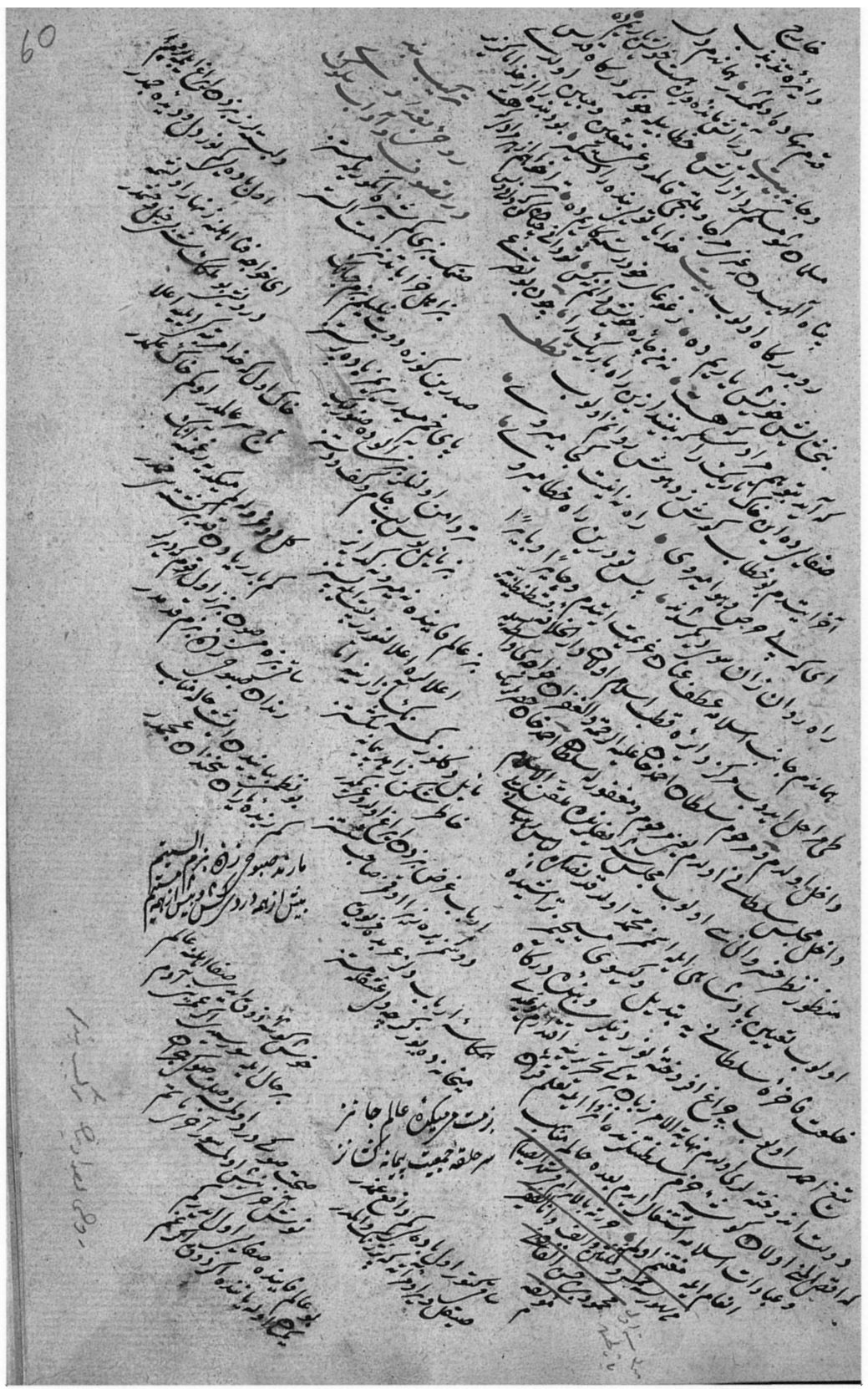

Ali Ninat Tarlan 60a 